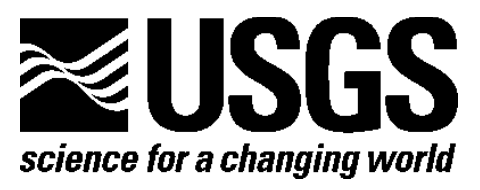

\title{
Earthquake Catalog for Estimation of Maximum Earthquake Magnitude, Central and Eastern United States-Part A, Prehistoric Earthquakes
}

By Russell L. Wheeler

Open-File Report 2014-1025-A

U.S. Department of the Interior

U.S. Geological Survey 


\section{U.S. Department of the Interior \\ SALLY JEWELL, Secretary}

\section{U.S. Geological Survey \\ Suzette M. Kimball, Acting Director}

U.S. Geological Survey, Reston, Virginia: 2014

For more information on the USGS-the Federal source for science about the Earth, its natural and living resources, natural hazards, and the environment-visit http://www.usgs.gov or call 1-888-ASK-USGS

For an overview of USGS information products, including maps, imagery, and publications, visit $h t t p: / / w w w . u s g s . g o v / p u b p r o d$

To order this and other USGS information products, visit $h$ ttp://store.usgs.gov

Suggested citation:

Wheeler, R.L., 2014, Earthquake catalog for estimation of maximum earthquake magnitude, Central and Eastern United States_Part A, Prehistoric earthquakes: U.S. Geological Survey Open-File Report 2014-1025-A, 26 p., http://dx.doi.org/10.3133/ofr20141025A.

ISSN 2331-1258 (online)

Any use of trade, firm, or product names is for descriptive purposes only and does not imply endorsement by the U.S. Government.

Although this information product, for the most part, is in the public domain, it also may contain copyrighted materials as noted in the text. Permission to reproduce copyrighted items must be secured from the copyright owner. 


\section{Contents}

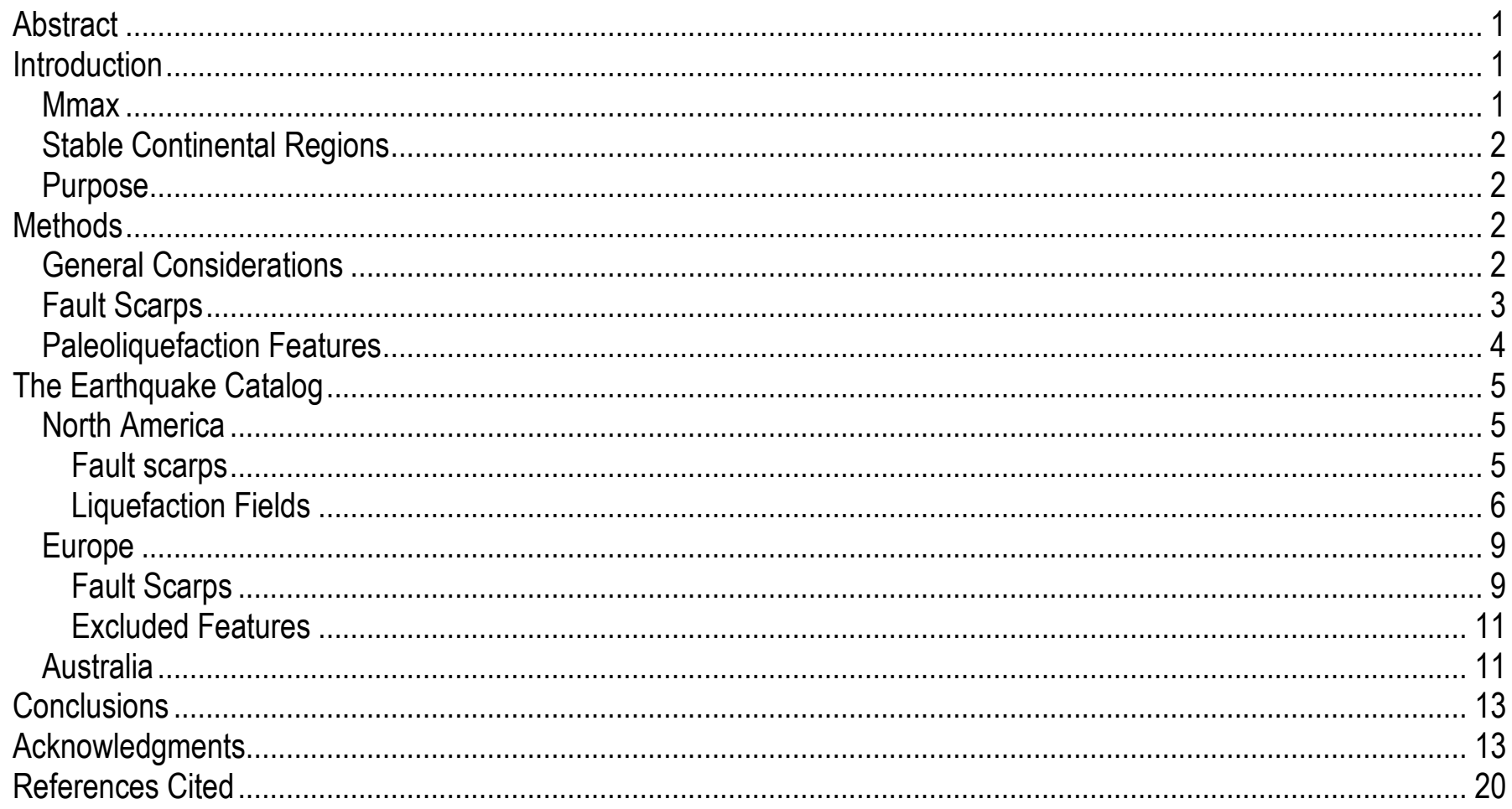

\section{Figures}

Figure 1. Geologic and paleoseismic setting of the Vincennes prehistoric earthquake. Location of earthquake from Wheeler and others (1997). Rest of figure modified from Wheeler and Cramer (2002). Shaded area in southwest corner of map represents Mesozoic and Cenozoic sediments and sedimentary rocks of Mississippi embayment. Craton (C) and extended margin (EM) source zones defined by Wheeler and Frankel (2000). Reelfoot rift, Rough Creek graben, and Wabash Valley fault system are in EM ................................................. 8

Figure 2. Fault scarps and other features in part of western Europe ……………………........................ 9 Figure 3. Selected fault scarps in the lower Rhine graben. Traces from Camelbeeck and others (2007). Two unlabeled faults bound the lower Rhine graben

Figure 4. Selected prehistoric fault scarps of Australia. Modified from Broadbent and Allan Cartography (1994) and Clark and others (2011b)

\section{Tables}

Table 1. Differences in magnitudes estimated from equations of Wells and Coppersmith (1994) and Leonard (2010)

Table 2. Magnitudes $M$ and their standard deviations $\sigma(M)$ from faults having measurements of both scarp

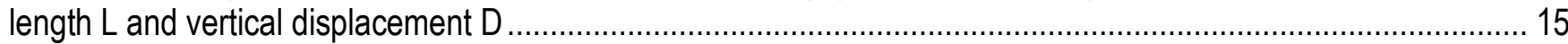

Table 3. Selected prehistoric earthquakes in stable continental regions: Descriptions .................................... 16

Table 4. Selected prehistoric earthquakes in stable continental regions: Analyses ....................................... 17

Table 5. Estimated standard deviations of magnitudes of prehistoric liquefying earthquakes, Illinois and Indiana

Table 6. Excluded features 


\section{Conversion Factors}

\begin{tabular}{|c|c|c|}
\hline Multiply & By & To obtain \\
\hline \multicolumn{3}{|c|}{ Length } \\
\hline$\overline{\text { foot }(\mathrm{ft})}$ & 0.3048 & \multirow{2}{*}{$\begin{array}{l}\text { meter }(\mathrm{m}) \\
\text { kilometer }(\mathrm{km})\end{array}$} \\
\hline mile (mi) & 1.609 & \\
\hline \multicolumn{3}{|l|}{ SI to Inch/Pound } \\
\hline Multiply & By & To obtain \\
\hline \multicolumn{3}{|c|}{ Length } \\
\hline$\overline{\text { meter }(\mathrm{m})}$ & 3.281 & foot (ft) \\
\hline kilometer $(\mathrm{km})$ & 0.6214 & mile (mi) \\
\hline
\end{tabular}

\section{Initialisms and Abbreviations}

CEUS Central and Eastern United States

EPRI Electric Power Research Institute

M magnitude

Mmax maximum earthquake magnitude

SCR stable continental region 


\title{
Earthquake Catalog for Estimation of Maximum Earthquake Magnitude, Central and Eastern United States-Part A, Prehistoric Earthquakes
}

\author{
By Russell L. Wheeler
}

\begin{abstract}
Computation of probabilistic earthquake hazard requires an estimate of Mmax, the maximum earthquake magnitude thought to be possible within a specified geographic region. This report is Part A of an Open-File Report that describes the construction of a global catalog of moderate to large earthquakes, from which one can estimate Mmax for most of the Central and Eastern United States and adjacent Canada. The catalog and Mmax estimates derived from it were used in the 2014 edition of the U.S. Geological Survey national seismic-hazard maps. This Part A discusses prehistoric earthquakes that occurred in eastern North America, northwestern Europe, and Australia, whereas a separate Part B deals with historical events.
\end{abstract}

\section{Introduction}

Mmax

Computation of probabilistic seismic hazard for a region requires an estimate of Mmax, which is the moment magnitude $\mathrm{M}$ of the largest earthquake that is thought to be possible within the region (Chinnery, 1979; Coppersmith and others, 1987; Wheeler, 2009a,b). Mmax estimates are used in the U.S. Geological Survey (USGS) national seismic-hazard maps (Petersen and others, 2008, and preceding editions of the maps). Engineering groups modify the hazard maps into design maps for incorporation into model building codes for residences and other low-rise buildings.

Mmax estimates are also utilized in site-specific hazard assessments for critical structures like large dams and nuclear power reactors. Electric Power Research Institute (EPRI) and others (2012) present a new methodology for reactor assessments in the Central and Eastern United States (CEUS: east of the Rocky Mountains). Their report and this one used the same information on prehistoric earthquakes in the CEUS. However, the different needs of our end-users required that EPRI and others (2012) and I used different methods to evaluate some information (EPRI and others, 2012, p. 1-4). Therefore, some of our M estimates for individual earthquakes differ. In addition, both EPRI and others (2012) and I searched for published evidence of prehistoric earthquakes in North America east of the Rocky Mountains. However, I also collected such evidence from western Europe and Australia.

In the sparsely seismically active CEUS, earthquakes large enough to be candidates for Mmax are rare. In most parts of the CEUS, the historical earthquake record is shorter than the lengths of time between occurrences of large earthquakes. Consequently, in most of the CEUS, Mmax cannot be observed and must be estimated indirectly from large earthquakes that have occurred worldwide in areas that are tectonically similar to the CEUS (Coppersmith and others, 1987; Coppersmith, 1994; Johnston and others, 1994; Wheeler, 2009a,b). 


\section{Stable Continental Regions}

Johnston (1989b) and Johnston and others (1994) developed the concept of stable continental regions (SCRs), which are regions worldwide that have undergone tectonism similar to that which has affected the CEUS. Kanter (1994) defined tectonic similarity in terms of four criteria. First, an SCR has undergone "no rifting or major extension or transtension younger than Paleogene," (Kanter, 1994, p. 23) that is, since 23.0 Ma (Gradstein and others, 2004). Additionally, an SCR has not undergone orogenic activity, deformation of orogenic forelands, or major anorogenic intrusive activity since the Early Cretaceous Epoch, or since 99.6 Ma (Gradstein and others, 2004). Kanter applied these criteria to Earth's continental crust and outlined SCRs on every continent (Broadbent and Allan Cartography, 1994).

The North American SCR consists of the United States and Canada east of the Rocky Mountains (Johnston and others, 1994). Wheeler and Frankel (2000) divided the CEUS part of the SCR into two zones that have different assigned values of Mmax (Petersen and others, 2008). The craton zone occupies the middle of the CEUS and is surrounded on the east and south by the extended margin. Most of the extended margin underwent Mesozoic extension as the Atlantic Ocean and Gulf of Mexico opened; the cratonward part of the margin underwent similar extension during Cambrian time as the predecessor ocean of the Atlantic opened. Johnston (1989b, 1994) pointed out that historical SCR earthquakes worldwide tended to reach larger magnitudes in extended margins than in cratons. Accordingly, the USGS national seismic-hazard maps assigned the CEUS extended margin a larger value of Mmax than the craton (Frankel and others, 1996, 2002; Petersen and others, 2008).

\section{Purpose}

The purpose of Part A is to describe the construction of a catalog of moderate to large known prehistoric SCR earthquakes. Part B does the same for historical earthquakes. The combined catalog allows estimation of CEUS Mmax, which will be discussed in a later paper.

\section{Methods}

\section{General Considerations}

The earthquakes most useful in constraining Mmax are independent, larger than any others that might have occurred on the same fault or fault system, and well characterized, as described in the following paragraphs. Numerous global catalogs list the instrumental seismicity of the world, so that searching for all cataloged instrumental earthquakes of a specific type is straightforward, if tedious. In contrast, I do not know of any comparable catalog of Earth's known prehistoric earthquakes. Most paleoseismic studies have been done in plate boundaries and other active continental crust, which are more seismically active than SCR crust. Accordingly, in compiling this catalog, I sought out only publications on SCR study areas that were already known to me or several colleagues. Those publications led me to a few more study areas. As a result, the catalog is complete for SCR crust in North America and Australia. Coverage of western Europe may be incomplete. The paleoseismic literature of other regions was not searched at all.

The focus on Mmax means that foreshocks and aftershocks are excluded. Additionally, if two or more large historical or prehistoric earthquakes occurred close enough together geographically that they are likely to have broken the same fault or fault system, then the catalog lists only the largest or best characterized earthquake. For example, large prehistoric earthquakes have been identified in the regions around New Madrid, Central United States (Tuttle and others, 2002); Charleston, South Carolina 
(Talwani and Schaeffer, 2001); and Kutch, India (Rajendran and Rajendran, 2001). However, the historical earthquakes of 1811-1812 around New Madrid, 1886 near Charleston, and 1819 in the Kutch area are better characterized than the prehistoric ones and are inferred to be about the same sizes. Thus, Part B lists the historical earthquakes and this Part A does not list the prehistoric ones. In contrast, eight prehistoric earthquakes in southern Illinois and southwestern Indiana are scattered over an area so large that they probably did not occur on the same fault (Obermeier, 1998). The catalog lists them all.

The catalog includes only prehistoric earthquakes that are sufficiently well characterized to constrain Mmax. Wheeler (2008) considered published descriptions of liquefaction fields and fault scarps produced by prehistoric and historical earthquakes. He concluded that earthquakes of approximately M6.5 or larger are likely to generate paleoseismic records that are extensive enough to allow estimates of $\mathrm{M}$, location, and age suitable for use in seismic-hazard assessments. Some smaller earthquakes are known to have produced a few liquefaction features or short surface fractures over a small area. Such sparse geologic records may serve only to establish a lower bound on Mmax. A paleoseismologist may be unable to determine whether the sparse liquefaction features or fractures were created by a small local earthquake or a large distant one (Obermeier, 1998).

\section{Fault Scarps}

If a prehistoric earthquake formed a surface rupture, $M$ is typically estimated from coseismic displacement, scarp length, or both. Scarp length is used as the independent variable in regression equations that predict either M or the logarithm of the moment Mo (Wells and Coppersmith, 1994; Leonard, 2010). I preferred the equation for $\log (\mathrm{Mo})$ as a function of scarp length that Leonard (2010, bottom section of his table 5) developed specifically for dip-slip SCR faults for three reasons. First, the regression equations of Wells and Coppersmith (1994) as a group are dominated by earthquakes that occurred in plate boundaries and active continental crust. Second, the equations of Leonard (2010) and those of Wells and Coppersmith (1994) predict similar M values for a given scarp length. Specifically, the first four equations in table 2A of Wells and Coppersmith (1994) provide M estimates for reverse, normal, and strike-slip faulting, and for all three faulting categories taken together. These M estimates differ from those calculated from Leonard's dip-slip equation by 0.1 -magnitude unit or less for scarps 20-60 km long (table 1). This range of lengths corresponds to M6.5-M7.3. The differences are 0.3 or less for scarps 10-120 km long, which corresponds to M6.0-M7.8. These are the M ranges of most interest for estimating CEUS Mmax. Third, the equations of Leonard (2010) have the advantage of selfconsistency, in that they are "relations that enable seismic moment, fault length, width, area, and displacement to be estimated from each other, with all these relations being consistent with the definition of seismic moment" (Leonard, 2010, p. 1,971). I also followed the recommendation of Leonard (2010, p. 1,985) and used his dip-slip equation for the few SCR strike-slip faults that are compiled here.

Nontectonic processes can form escarpments that mimic tectonic scarps (McCalpin, 2009). Accordingly, I only compiled lengths of those scarps that have been trenched at one or more sites to expose a tectonic fault having enough slip to have formed the scarp. Estimation of Mmax from scarp length implies that at least one earthquake broke the entire length of the scarp.

Estimation of $\mathrm{M}$ from displacement requires a measurement that is associated with a single earthquake. The average of the cumulative displacement from two or more earthquakes is not a usable estimate of Mmax unless other evidence demonstrates that all the earthquakes were of the same M. Measurements of partially exposed displacements are not used, because they provide only a lower bound on $\mathrm{M}$. 
Leonard (2010) does not list a regression equation for displacement. I used those of Wells and Coppersmith (1994). If displacements have been measured for each of two or more earthquakes, the largest value is used because it is likely to represent the largest earthquake. The regression equations used are those for $\mathrm{M}$ as a function of average displacement (table 2B of Wells and Coppersmith, 1994). Average displacement is used instead of maximum displacement because usually only one or a few trench sites are studied on any given SCR fault. These few trenches are unlikely to sample the single maximum displacement along the fault.

Dip-slip displacements for which there is reason to suspect a significant associated strike-slip component are not used, because using the dip-slip component alone would cause underestimation of $\mathrm{M}$. For example, if the strike-slip component is much smaller than the dip-slip component, then the impact on $\mathrm{M}$ of ignoring the strike-slip component is negligible. In contrast, if the two components are equal, and if the strike-slip component were ignored, then total displacement and moment would both be underestimated by 29 percent but $\mathrm{M}$ by only 0.1 -magnitude unit. However, if the strike-slip component were twice as large as the dip-slip component, then total displacement and moment would be underestimated by 55 percent and $\mathrm{M}$ by approximately 0.2 units. For strike slip three times as large as dip slip, the underestimation of total displacement and moment would be 68 percent, and $\mathrm{M}$ would be underestimated by about 0.3-magnitude units. Of the trenched faults that are considered here, arguments for significant strike-slip displacement were made only for the reverse North Hyden and Roopena faults in Australia (Crone and others, 2003).

All of the faults for which I calculated M have measured scarp lengths. Four of the faults also have measured single-earthquake displacements. For these four, $\mathrm{M}$ values from length and displacement were combined in a weighted average, with weights set as the inverses of the variances of the $M$ values (Bevington and Robinson, 1992, p. 59; Johnston, 1996b, p. 647-648). Following these authors, the standard deviation $\sigma(\mathrm{M})$ of a combined $\mathrm{M}$ was calculated similarly (table 2 ).

I follow Wells and Coppersmith (1994), Johnston (1996c), and Leonard (2010) in giving $\sigma(\mathrm{M})$ to two decimal places; Johnston (1996a,b) give three places. In most cases the second decimal place is not significant. It is provided solely to reduce round-off errors that would propagate through future calculations that use $\sigma(\mathrm{M})$.

Johnston (1996b) observed that combining two or more M estimates and their standard deviations in this way commonly results in a combined $\sigma(\mathrm{M})$ that is smaller than the individual standard deviations; table 2 shows examples. This result occurs because each individual $\mathrm{M}$ estimate is subject only to its own constraints, which are represented by the estimate's standard deviation. In contrast, the combined $\mathrm{M}$ is subject to the constraints of all the individual $\mathrm{M}$ estimates. Therefore, the combined $\mathrm{M}$ estimate has smaller uncertainty than any of the individual estimates. Part B discusses the matter in more detail.

\section{Paleoliquefaction Features}

There are two main ways of estimating $M$ from liquefaction features. First, the magnitude-bound method is based on measuring the distance from the epicentral area of the liquefying earthquake to the farthest known liquefaction feature that is attributed to the earthquake (Ambraseys, 1988). This distance is then compared to other largest-liquefaction distances that have been measured for instrumental earthquakes of known M (Ambraseys, 1988; Obermeier, 1998; McNulty and Obermeier, 1999; Olson and others, 2005; Castilla and Audemard, 2007). Second, the geotechnical method involves measuring and analyzing physical properties of individual liquefaction features (Green and others, 2005). Obermeier (2009) and Tuttle and Hartleb (2012) discuss the uncertainties of paleoliquefaction data and magnitudes estimated from them. 


\section{The Earthquake Catalog}

Tables 3 and 4 summarize characteristics of the 26 fault scarps and liquefaction fields listed in the catalog. The most recent surface ruptures along the faults, and formation of the liquefaction fields, are late Pleistocene to late Holocene in age.

\section{North America}

\section{Fault scarps}

The four faults discussed below were reactivated most recently during 12.8-1.2 ka (table 3). The left-lateral Meers fault in Oklahoma has a secondary component of reverse faulting and a measured scarp length but no reported measurements of single-earthquake displacement. The normal Cheraw fault in southeastern Colorado has measured vertical displacements for three prehistoric earthquakes in addition to a measured scarp length. The Cheraw scarp is $45 \mathrm{~km}$ long, which implies M7.1 with $\sigma(\mathrm{M})=$ 0.14 , whereas the displacement of $1.5 \mathrm{~m}$ predicts $\mathrm{M} 6.9$ with $\sigma(\mathrm{M})=0.33$. The two M estimates and two $\sigma(\mathrm{M})$ estimates from the Cheraw fault were combined as summarized earlier in the "Methods" section to give $\mathrm{M} 7.1$ and $\sigma(\mathrm{M})=0.13$ (table 2).

The Idalia Hill fault of southeastern Missouri is within a linear, northeast-trending zone of mapped and trenched paleoliquefaction features, stream anomalies, faults that are exposed in trenches and imaged in high-resolution seismic-reflection profiles, and aligned topographic lineaments (Baldwin and others, 2006). Figure 1 of Baldwin and others (2006) shows that the zone is at least $91 \mathrm{~km}$ long. No through-going scarp is evident in the figures or descriptions of Baldwin and others (2006). Individual prehistoric earthquakes have been recognized and dated at three sites in the linear zone, but the dates are too poorly constrained to demonstrate whether or not any of the earthquakes have ruptured more than one of the sites (Vaughn, 1994; Harrison and others, 1999; Baldwin and others, 2006). However, within the 91-km-long zone, two of the aligned topographic lineaments are continuous scarps $15-20 \mathrm{~km}$ long. The 17-km-long scarp at the Idalia Hill site is the better characterized (Baldwin and others, 2004), and I use this length to estimate $\mathrm{M}$.

Similar to the discontinuous scarps along and near the Idalia Hill fault, collinear and en echelon, northwest-facing topographic scarps form a linear, northeast-trending zone along $80 \mathrm{~km}$ of the southeast margin of the Reelfoot rift in western Tennessee (Wyatt and Stearns, 1988; Cox and others, 2001). Interpretations of shallow reflection profiles, electrical surveys, cores, and trenches show that the scarps are underlain by late Quaternary faults that dip steeply both northwest and southeast (Cox and others, 2006). Some faults have their northwest sides uplifted, whereas other faults have the opposite throw. However, unlike the 91-km-long zone containing the Idalia Hill fault, interpretations of maps of aeromagnetic gradients, maps of depths to magnetic basement, and seismic-reflection profiles along the southeastern margin of the rift show that the aligned scarps and late Quaternary faults of the rift margin overlie a through-going, deep-seated fault zone (Hildenbrand and Hendrix, 1995; Parrish and Van Arsdale, 2004). These authors concluded that the $80-\mathrm{km}$ zone along the rift margin is underlain at depths of $1-7 \mathrm{~km}$ by a continuous system of basement-cutting normal faults that dropped their northwest sides down as much as $3 \mathrm{~km}$. The normal-fault system is as wide as $10 \mathrm{~km}$ at the top of Precambrian basement. Most of the faulting is of Cambrian age, and several of the faults were reactivated in Tertiary transpression (Parrish and Van Arsdale, 2004). The presence of the continuous system of large basement faults that had Tertiary reactivation implies the possibility that the entire $80-\mathrm{km}$ zone could break in a single rupture. Cox and others (2006) interpreted the surficial scarps and faults as a right-lateral fault system $80 \mathrm{~km}$ long, and I use this length to estimate M. 


\section{Liquefaction Fields}

Eight prehistoric earthquakes produced liquefaction features consisting mainly of sand dikes in southwestern Indiana and southern Illinois during 12.0-2.0 ka (Munson and others, 1997; Obermeier, 1998; McNulty and Obermeier, 1999; Tuttle and others, 1999). M estimates from paleoliquefaction fields come from the magnitude-bound or geotechnical methods, not regressions, and the estimates lack regression-based values of $\sigma(\mathrm{M})$. Obermeier (2009) and Tuttle and Hartleb (2012) considered geological and analytical sources of uncertainty in liquefaction-based $\mathrm{M}$ estimates. Tuttle and Hartleb (2012) suggested that together the sources of uncertainty produce $\sigma(\mathrm{M})$ values of approximately $0.25-$ to $0.6-\mathrm{M}$ units. Judging from the size of an earthquake's liquefaction field as measured from published maps, and the number of sites reported to expose liquefaction features, I qualitatively assigned a standard deviation to each paleoliquefaction-based $\mathrm{M}$ estimate (table 5) as follows.

The Vincennes liquefaction field far exceeds the seven others in size and number of reported liquefaction sites. Both the largest liquefaction field and the largest number of exposures may cause the Vincennes $M$ estimate to be the least distorted by any local anomalies in sediment liquefaction potential. Therefore, the Vincennes $M$ may have the smallest $\sigma(\mathrm{M})$ among the eight earthquakes, perhaps 0.25 . However, the Vincennes liquefaction field consists mainly of sand dikes, not sand blows (Obermeier, 1998). Tuttle and Hartleb (2012) pointed out that sand dikes can form in the subsurface but without penetrating upward to the surface, so that the most distant dikes from the earthquake location can be harder to recognize than the most distant sand blows. Accordingly, I assigned the Vincennes M an uncertainty of 0.3 .

There are two recent $M$ estimates of the Vincennes earthquake. Green and others (2005) used geotechnical measurements to estimate the Vincennes M as 7.5. Olson and others (2005) modified the magnitude-bound method to match geological conditions of the Central United States and estimated the Vincennes $M$ as 7.1 to 7.3. In a 2007 conference paper and a 2009 workshop, Olson reported a revised value of M7.5 with an uncertainty of 0.3 (Olson and others, 2007; EPRI and others, 2012, p. F-26; S.M. Olson, written commun., August 17, 2012). After considering the results of Green and others (2005), Olson and others (2007), and Tuttle and Hartleb (2012), I assigned the earthquake M7.5 and $\sigma(\mathrm{M})=0.3$.

At the other extreme of liquefaction fields, the Iona and Elnora earthquakes each are known only from a few sand dikes in one exposure. The most likely $\mathrm{M}$ for the earthquakes may be 6.0 (Munson and others, 1997; Obermeier, 1998). This value was chosen to be slightly larger than the estimated threshold $\mathrm{M}$ for producing liquefaction in the sediments of the exposures that contain the dikes (Obermeier, 1998). However, Obermeier (1998) noted that the true M could be smaller than 6.0 if the earthquakes occurred at or near the liquefied sites, or much larger if they were distant. This large uncertainty points toward a standard deviation of 0.6, the largest value suggested by Tuttle and Hartleb (2012). Such small earthquakes provide only a weak lower limit on Mmax. However, I kept them for consistency, with the lower M limit of the catalog of historical earthquakes that Part B of this report describes.

Between these two extremes are five other liquefaction fields (table 5). All five fields cover areas much smaller than that of the Vincennes field and have a small fraction as many reported liquefaction sites. Therefore, lower $\mathrm{M}$ values calculated for these five fields reflect the influence of local geologic and hydrological anomalies more than the Vincennes M does. The Vallonia, Martinsville, Shoal Creek, and Springfield liquefaction fields cover areas within a factor of two of each other. The Skelton field is a factor of four to seven larger than those four fields. Accordingly, I assigned $\sigma(\mathrm{M})$ of 0.4 to the Skelton M and 0.5 to the other four M values.

The Mmax zone within which the Vincennes earthquake occurred is uncertain. In the Central United States, the extended-margin Mmax source zone protrudes northeastward into the craton Mmax zone (Wheeler and Frankel, 2000; Wheeler and Cramer, 2002; fig. 1). The epicentral area of the 
earthquake is presumed to have been at or near a cluster of the largest liquefaction features that Obermeier (1998) attributed to the earthquake. This cluster is in the craton zone, about $20 \mathrm{~km}$ north of the northern end of the Wabash Valley fault system. The fault system is part of the extended-margin Mmax zone. However, the rupture zone of the M7.5 earthquake would have been approximately $80 \mathrm{~km}$ long (Leonard, 2010). Therefore, the earthquake rupture could have started in either the craton or the extended margin. The rupture could have propagated from either zone into the other. For these reasons, the Mmax zone to which the earthquake should be assigned is not obvious.

The Wabash Valley fault system does not crop out. It is known from mine, well, and geophysical data (Nelson, 1995). These subsurface data show that offset across the faults decreases northward (Bear and others, 1997). The northward decrease in offset implies that the ability to detect the northern end of the fault system using the subsurface data may be limited. Therefore, the fault system may extend farther north than is recognized. Accordingly, the earthquake could have occurred either in the Wabash Valley fault system and the extended margin or within the craton on an unknown fault system, with almost equal likelihood. Furthermore, Johnston (1989b, 1994), Petersen and others (2008), and this report's companion Part B show that large earthquakes tend to be more common historically in the extended margins of the world than in cratons. Despite the location of the epicentral area in the craton, I assigned the earthquake to the extended margin because of the earthquake's M; the presence, orientation, and proximity of the Wabash Valley fault system; and the likelihood that the fault system extends farther north than has been mapped.

This report excludes several paleoseismic studies of confirmed or probable liquefaction features (table 6). Those studies have not yet constrained M narrowly enough for use in estimating Mmax. 


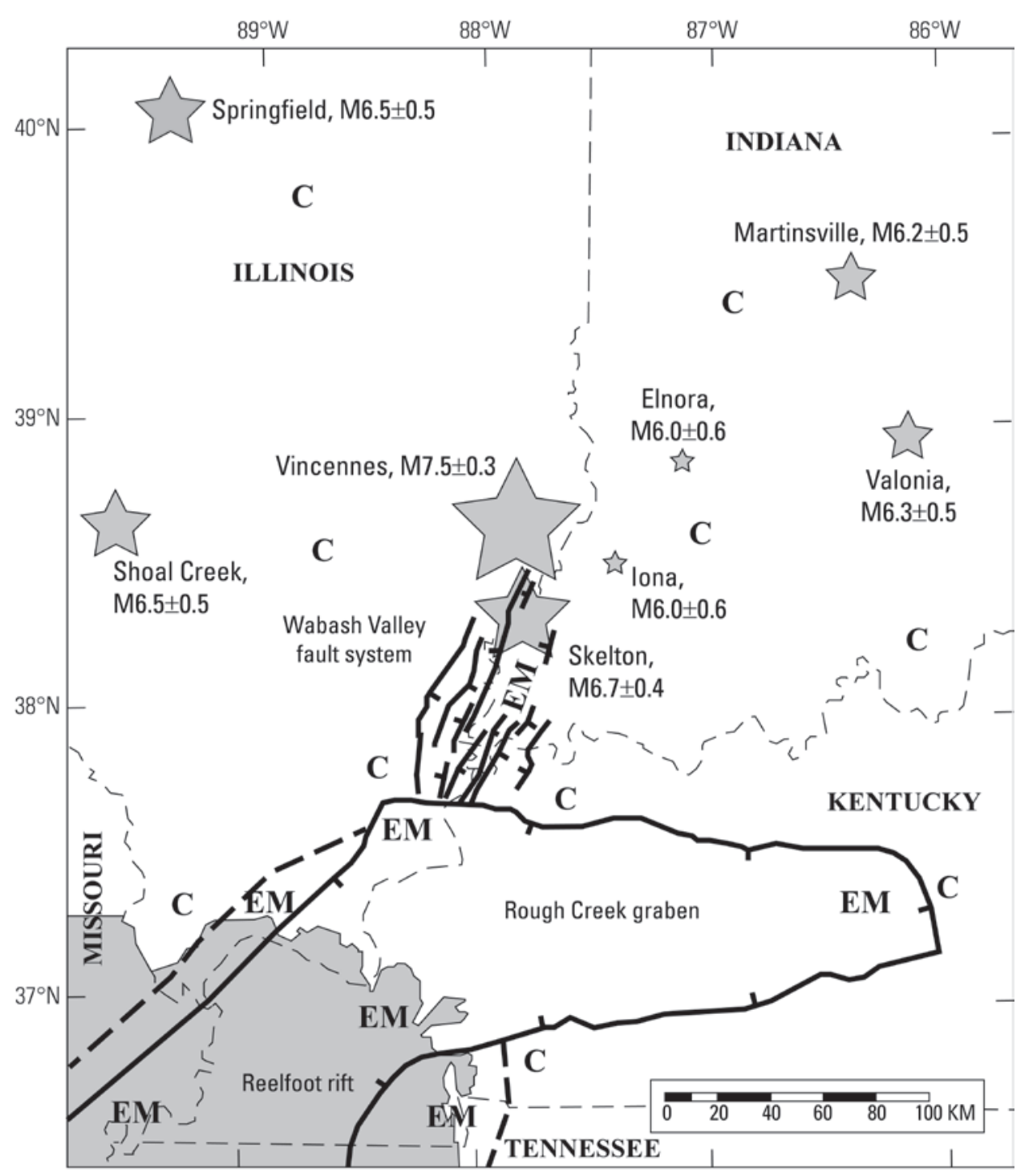

\section{EXPLANATION}

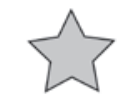

Approximate epicentral area of prehistoric earthquake, as inferred from locations of largest liquefaction features that are attributed to the earthquake. Size of star indicates approximate earthquake magnitude $M$. Values of $M$ and its uncertainty from table 4.

ـ Major fault or fault zone. Tick is on side of fault that moved down with respect to other side.

- - Boundary of the Reelfoot rift seismic-source zone that is outside the major rift-bounding faults delineated by the solid lines (Wheeler and Frankel, 2000).

Figure 1. Geologic and paleoseismic setting of the Vincennes prehistoric earthquake. Location of earthquake from Wheeler and others (1997). Rest of figure modified from Wheeler and Cramer (2002). Shaded area in southwest corner of map represents Mesozoic and Cenozoic sediments and sedimentary rocks of Mississippi embayment. Craton (C) and extended margin (EM) source zones defined by Wheeler and Frankel (2000). Reelfoot rift, Rough Creek graben, and Wabash Valley fault system are in EM. 


\section{Europe}

\section{Fault Scarps}

Publications on three faults in western Europe describe trenches that demonstrate tectonic movement and scarp lengths that are well enough described to support $\mathrm{M}$ estimates (figs. 2 and 3; tables 3 and 4). The most recent ruptures along the scarps occurred 14.5-0.5 ka. Seven other western European faults and other features lack demonstrated tectonic movement, have poorly described scarp lengths, or are not in SCR crust (figs. 2 and 3; table 6).

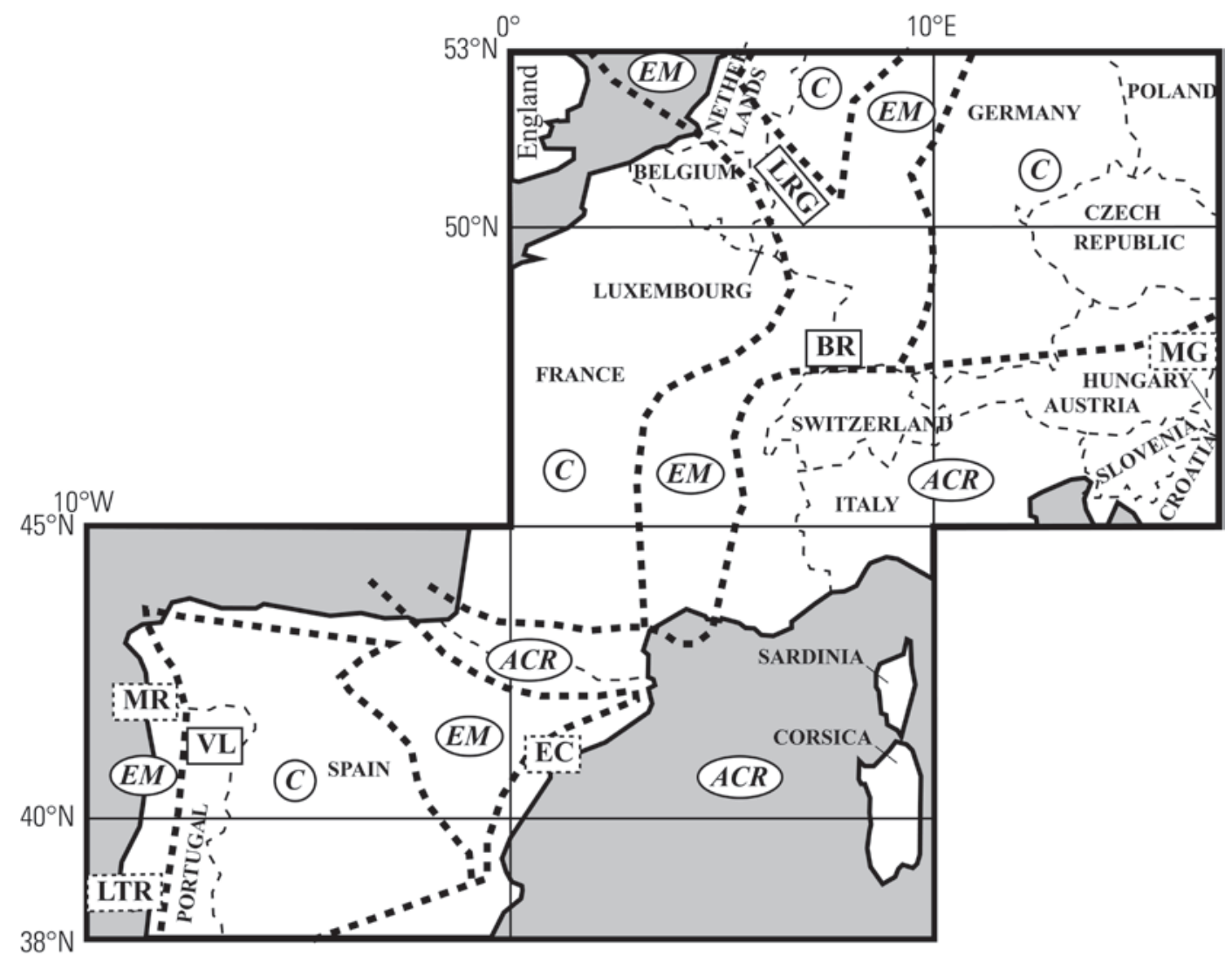

EXPLANATION

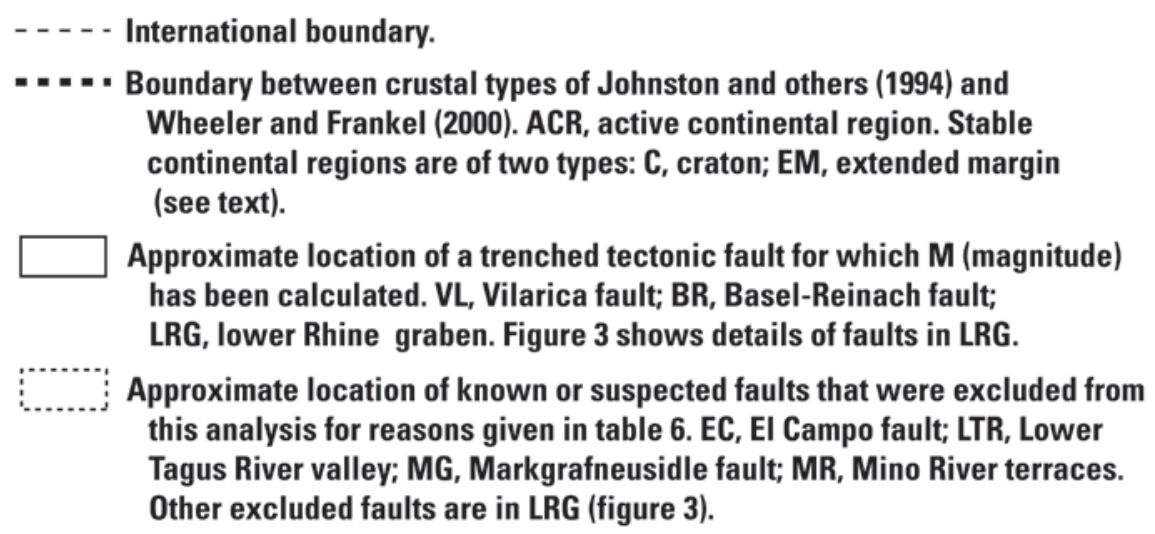

Figure 2. Fault scarps and other features in part of western Europe. 


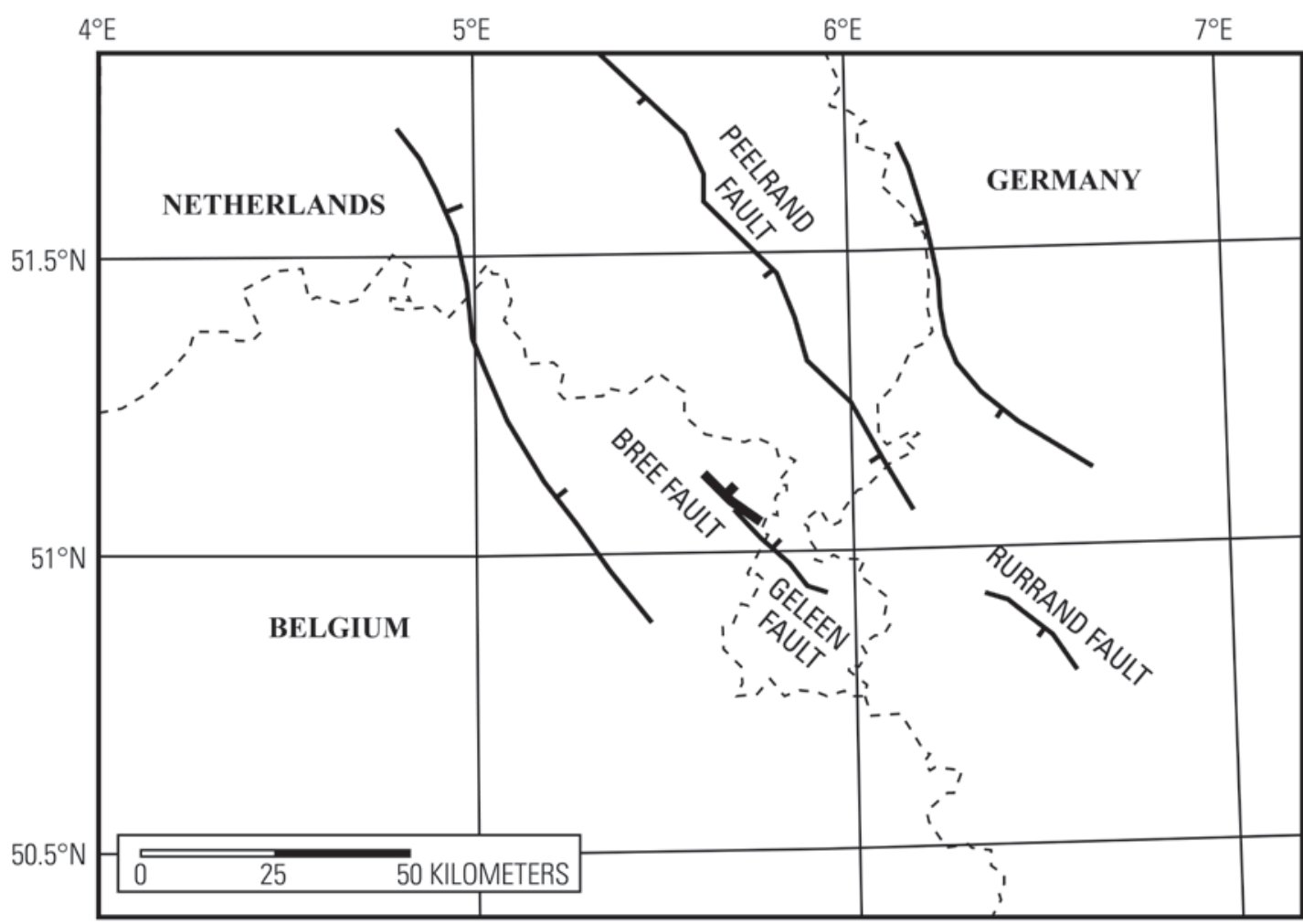

EXPLANATION

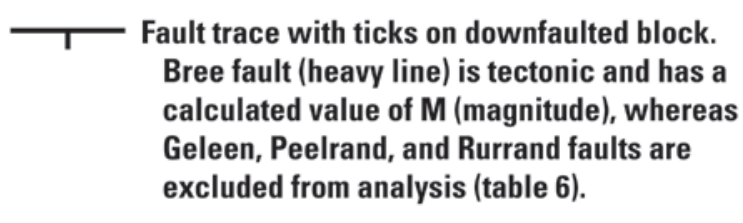

- - - - - International border

Figure 3. Selected fault scarps in the lower Rhine graben. Traces from Camelbeeck and others (2007). Two unlabeled faults bound the lower Rhine graben.

The Vilarica fault of northern Portugal underwent left-lateral strike slip in cratonic SCR crust (Rockwell and others, 2009). Rockwell and others (2009) trenched the fault at two sites and mapped its scarp as $75 \mathrm{~km}$ long. As noted earlier in the "Methods" section, the scarp length of the strike-slip fault may be converted to $M$ and $\sigma(M)$ best with the dip-slip SCR equation of Leonard (2010) (table 4).

The Bree fault is a normal fault within the lower Rhine graben in northeastern Belgium. The Rhine graben is actively extending (Camelbeeck and others, 2007), but Kanter (1994) considered it SCR crust because most of the extension is older than the Neogene Subperiod (see earlier section on "Stable Continental Regions"). The largest vertical displacement measured on the Bree fault is $1.25 \mathrm{~m}$, and the scarp length is $11.5 \mathrm{~km}$ (Camelbeeck and others, 2007). The displacement implies M6.8 with $\sigma(\mathrm{M})=$ 0.33 , whereas the scarp length predicts M6.1 with $\sigma(\mathrm{M})=0.14$. As described in the "Methods" section, the $\mathrm{M}$ estimates from scarp length and displacement were combined with the method of Johnston (1996b) to give M6.2 with $\sigma(\mathrm{M})=0.13$ (table 2). 
The north-striking Basel-Reinach fault of southern Switzerland is exposed north of the easttrending thrust faults and associated folds of the Jura province of the Alps (Ferry and others, 2005). The Jura is a young deformed orogenic foreland. Thus, the Jura is active continental crust instead of SCR crust (Broadbent and Allan Cartography, 1994; Kanter, 1994). The south end of the Basel-Reinach scarp is approximately $1 \mathrm{~km}$ north of the exposed thrust front of the Jura. Ferry and others (2005) suggested that the fault extends farther southward, under the thrust sheets. Therefore, the Basel-Reinach fault is in transitional SCR crust, which Johnston (1994) defined as SCR crust within $40 \mathrm{~km}$ of an SCR edge (table 4). The Basel-Reinach scarp is $8 \mathrm{~km}$ long (Meghraoui and others, 2001). In addition, the largest vertical displacement measured on the fault is $1.0 \mathrm{~m}$ (Camelbeeck and others, 2007). The scarp length implies M5.8 and $\sigma(\mathrm{M})=0.14$. The displacement implies M6.8 and $\sigma(\mathrm{M})=0.33$. These two estimates were combined into M6.0 and $\sigma(\mathrm{M})=0.13$ (table 2).

\section{Excluded Features}

Table 6 lists several fault scarps that are too poorly characterized to calculate M, are not clearly of tectonic origin, have no active fault that has been studied in a trench or other exposure, or are not in SCR crust.

Long fault scarps in northern Sweden indicate that a sequence of large late-glacial earthquakes occurred during the early Holocene (Lundqvist and Lagerback, 1976; Morner, 2004, 2005). The burst of large-M seismicity has been attributed to release of accumulated stress as the Fennoscandian ice sheet melted and the crust rebounded (Lundqvist and Lagerback, 1976; Johnston, 1989a; Muir Wood, 1989). However, this rapidly changing tectonic environment no longer exists (Muir Wood, 1989). Accordingly, I excluded these earthquakes from estimation of Mmax.

\section{Australia}

All Australian scarps listed in tables 3 and 4 have reported lengths from which $\mathrm{M}$ has been estimated. All the scarps have been trenched. All had their most recent surface ruptures in 83-8.6 ka.

Only the Lake Edgar scarp also has a displacement measurement that meets the criteria listed earlier under "Fault Scarps" in the "Methods" section (table 2). Clark and others (2011a) summarized geologic and geophysical information that indicate the Lake Edgar fault may be within a fragment of reactivated Proterozoic cratonic crust. The fragment is surrounded by the much larger Australian extended margin. Accordingly, I assigned the fault to the extended margin (fig. 4). Like the Cheraw, Bree, and Basel-Reinach faults, the Lake Edgar fault has both a measured scarp length $(26.6 \mathrm{~km})$ and a measured largest single-earthquake displacement $(3.1 \mathrm{~m})$. The length predicts $\mathrm{M} 6.7$ and $\sigma(\mathrm{M})=0.14$, whereas the displacement implies M6.7 and $\sigma(\mathrm{M})=0.50$, for combined values of M6.7 and $\sigma(\mathrm{M})=0.13$ (table 2).

In addition to the Lake Edgar fault, only the Waratah fault is in extended-margin crust. Five of the 11 Australian faults shown on figure 4 are within the craton: North Hyden, Lort River, Dumbleyung, Roopena, and Cadell. 


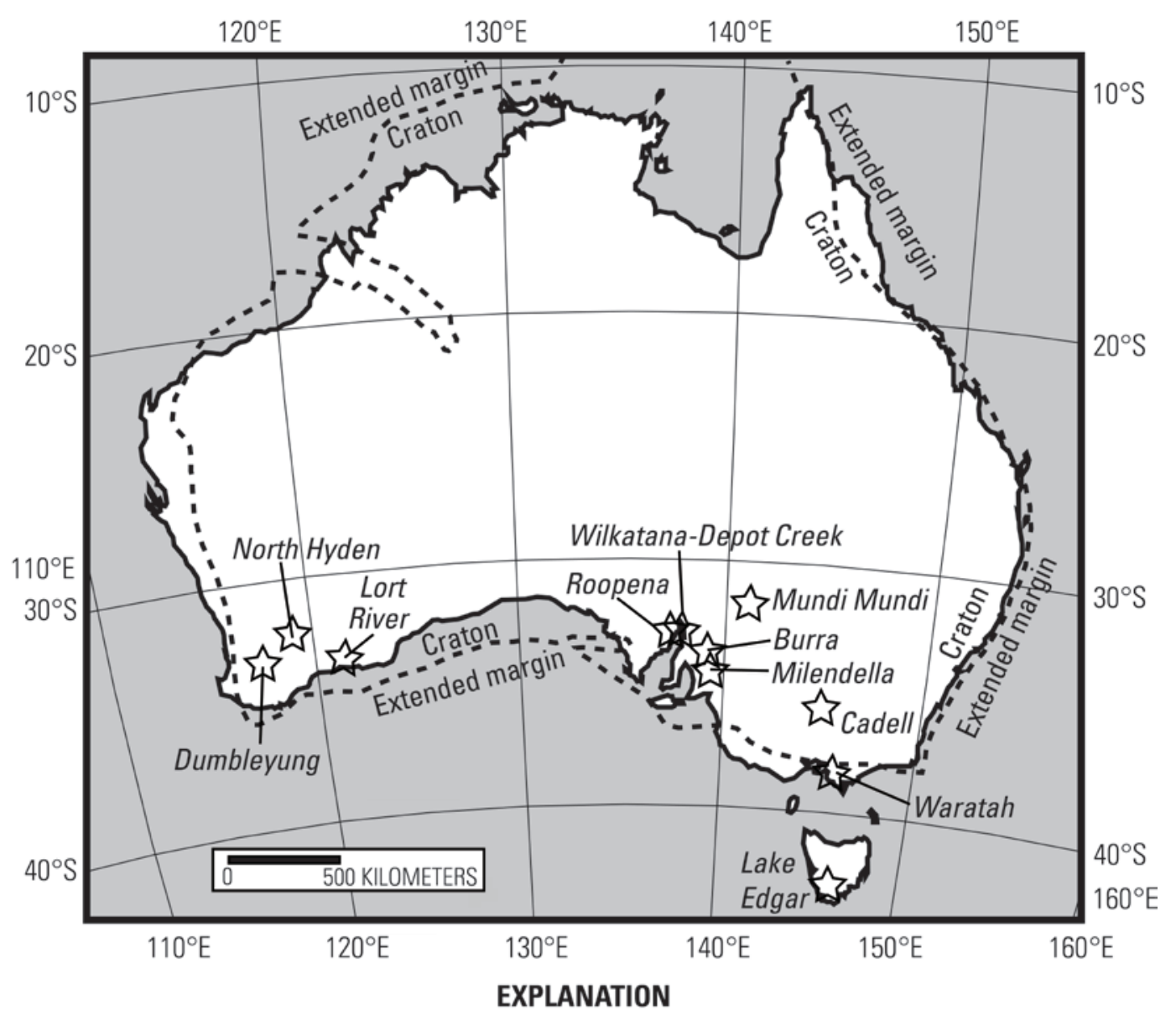

EXPLANATION

$\leadsto$ Locations of scarps caused by prehistoric Australian earthquakes (tables 3 and 4). Scarp names in italics.

- - - Boundary between two types of crust that are tectonic analogs to parts of the Central and Eastern United States and adjacent Canada (Johnston and others, 1994; Wheeler and Frankel, 2000; Petersen and others, 2008; Clark and others, 2011). In both Australia and eastern North America, the cratons occupy the central parts of the continents, and the extended margins surround the cratons and extend offshore.

Figure 4. Selected prehistoric fault scarps of Australia. Modified from Broadbent and Allan Cartography (1994) and Clark and others (2011b).

The Burra, Milendella, Mundi Mundi, and Wilkatana-Depot Creek faults are in the Sprigg orogeny domain of Clark and others (2011b). The domain is undergoing rapid east-west shortening that creates north-striking active faults, faulting-generated topographic relief, and as much as $200 \mathrm{~m}$ of net offset (Clark and others, 2011b). Clark and others (2011b) suggest that the faulting is driven by plate motions that began 10-5 Ma; Clark and others also note that no other part of the Australian craton has such rapid neotectonic deformation. Nonetheless, Clark and others (2011b) retain the domain within the craton instead of assigning it to the extended margin. 


\section{Conclusions}

This report lists 26 prehistoric SCR earthquakes that were recognized from liquefaction fields or fault scarps. A more systematic search of the paleoseismic literature for other SCRs might find more scarps. Clark and others (2011b) found many scores of possible fault scarps throughout Australia by combining digital elevation data with image-processing software. A similar search of the Great Plains of the United States and Canada might be similarly successful.

For calculation of M from scarp length, I preferred the equation of Leonard (2010) for SCR dip-slip instead of the equations of Wells and Coppersmith (1994, their table 2A). The reasons were described earlier in "Fault Scarps" in the "Methods" section. In addition, the Wells and Coppersmith equations underpredict M compared to Leonard's equation (table 1). The underprediction increases with M, so the choice of equations from Leonard (2010) or Wells and Coppersmith (1994) will have the largest effect on $\mathrm{M}$ for the large earthquakes that are the most important for Mmax estimation. It is advisable to use Leonard's equation for work with SCR earthquakes.

All of the 26 prehistoric earthquakes have reported scarp lengths, but only four of them also have reported single-earthquake displacements (table 2). The table shows that $\mathrm{M}$ from displacement differs from $\mathrm{M}$ from scarp length by 0.0-1.0 $\mathrm{M}$ units. However, because displacement $\mathrm{M}$ has much larger standard deviations than scarp-length $\mathrm{M}$, when both $\mathrm{M}$ estimates are combined for individual faults, then the $\mathrm{M}$ difference decreases to 0.0-0.2. Standard deviations of the combined $\mathrm{M}$ values are 0.1-M unit smaller than those of the corresponding scarp-length $\mathrm{M}$. These comparisons suggest that if scarp length and displacement are both reported for a particular prehistoric earthquake, then it may be worth calculating $\mathrm{M}$ from displacement in order to combine it with $\mathrm{M}$ calculated from scarp length, thereby reducing $\sigma(\mathrm{M})$. Displacement $\mathrm{M}$ by itself may be too imprecise to use without an accompanying scarp-length $\mathrm{M}$.

\section{Acknowledgments}

I thank D. Clark, A.J. Crone, K.M. Haller, A.C. Johnston, M. Leonard, S.M. Olson, and M.P. Tuttle for discussions, advice, and preprints. Johnston kindly provided copies of his digital maps of the world's stable continental regions. Reviews by K.M. Haller, R.W. Briggs, and J.L. Slate improved the manuscript. 
Table 1. Differences in magnitudes estimated from equations of Wells and Coppersmith (1994) and Leonard (2010).

[L, scarp length in kilometers (km); L10, magnitude M calculated from the equation of Leonard (2010, his table 5) for dipslip faulting in stable continental regions; WC(R), M calculated from the equation of Wells and Coppersmith (1994, their table 2A) for surface-rupture length formed by reverse faulting and similarly for WC(SS) (strike-slip faulting), WC(N) (normal faulting), and WC(All) (all three faulting styles grouped together)]

\begin{tabular}{lccccr}
\hline $\mathbf{L}(\mathbf{k m})$ & L101 & $\begin{array}{c}\text { L10- } \\
\text { WC(R) }\end{array}$ & $\begin{array}{c}\text { L10- } \\
\text { WC(SS) }\end{array}$ & $\begin{array}{c}\text { L10- } \\
\text { WC(N) }\end{array}$ & $\begin{array}{r}\text { L10- } \\
\text { WC(All) }\end{array}$ \\
\hline 10 & 5.99 & -0.23 & -0.29 & -0.19 & -0.25 \\
20 & 6.49 & -0.10 & -0.13 & -0.09 & -0.10 \\
30 & 6.78 & -0.02 & -0.03 & -0.03 & -0.01 \\
40 & 6.99 & 0.03 & 0.04 & 0.01 & 0.05 \\
50 & 7.15 & 0.08 & 0.09 & 0.05 & 0.10 \\
60 & 7.28 & 0.11 & 0.13 & 0.08 & 0.14 \\
70 & 7.39 & 0.14 & 0.17 & 0.10 & 0.17 \\
80 & 7.49 & 0.17 & 0.20 & 0.12 & 0.20 \\
90 & 7.58 & 0.19 & 0.23 & 0.14 & 0.23 \\
100 & 7.65 & 0.21 & 0.25 & 0.15 & 0.25 \\
110 & 7.72 & 0.23 & 0.28 & 0.17 & 0.27 \\
120 & 7.78 & 0.25 & 0.30 & 0.18 & 0.29 \\
130 & 7.84 & 0.26 & 0.31 & 0.19 & 0.31 \\
140 & 7.90 & 0.28 & 0.33 & 0.20 & 0.33 \\
150 & 7.95 & 0.29 & 0.35 & 0.21 & 0.34 \\
160 & 7.99 & 0.30 & 0.36 & 0.22 & 0.36 \\
170 & 8.04 & 0.32 & 0.38 & 0.23 & 0.37 \\
180 & 8.08 & 0.33 & 0.39 & 0.24 & 0.38 \\
\hline
\end{tabular}

${ }^{1}$ L10 equations use L in meters, whereas WC94 equations use L in kilometers. 
Table 2. Magnitudes $M$ and their standard deviations $\sigma(M)$ from faults having measurements of both scarp length $L$ and vertical displacement $D$. [Each Ref field cites sources of preceding one or two entries in that row. All faults are normal except steeply dipping Lake Edgar reverse fault. M(L) is M calculated from $\mathrm{L}$ and similarly for $\sigma(\mathrm{L}), \mathrm{M}(\mathrm{D})$, and $\sigma(\mathrm{D})$. If two or more $\mathrm{D}$ values are reported for a fault, largest is used as probably representing largest earthquake. Most stable continental region faults are trenched at one or very few sites. The trenches are unlikely to sample maximum $\mathrm{D}$ along the fault.

Accordingly, regression equation of WC94 (their table 2B) for M(average D) is more appropriate than the one for M(maximum D). Last two columns list combined $M$ and its $\sigma(M)$ for each fault (see text). Standard deviations given to two decimal places here and in later tables to reduce round-off errors (see text); $\mathrm{km}$, kilometers]

\begin{tabular}{|c|c|c|c|c|c|c|c|c|c|c|c|c|c|}
\hline Fault name & Locale & $L(\mathrm{~km})$ & Ref 1 & $M(L)$ & $\sigma(\mathrm{L})$ & Ref $^{1}$ & $\mathrm{D}(\mathrm{m})$ & Ref1 & $M(D)$ & $\sigma(D)$ & Ref $^{1}$ & $M$ & $\sigma(M)$ \\
\hline Cheraw & Colorado, U.S.A. & 45 & C97 & 7.1 & 0.14 & L10 & 1.5 & C97 & 6.9 & 0.33 & WC94 & 7.1 & 0.13 \\
\hline Basel-Reinach & Switzerland & 8 & M01 & 5.8 & 0.14 & L10 & 1.0 & F05 & 6.8 & 0.33 & WC94 & 6.0 & 0.13 \\
\hline Bree & Belgium & 11.5 & $\mathrm{C} 07$ & 6.1 & 0.14 & L10 & 1.25 & $\mathrm{C} 07$ & 6.8 & 0.33 & WC94 & 6.2 & 0.13 \\
\hline Lake Edgar & Tasmania, Australia & 26.6 & $\mathrm{CO} 11$ & 6.7 & 0.14 & L10 & 3.1 & $\mathrm{CO} 11$ & 6.7 & 0.50 & WC94 & 6.7 & 0.13 \\
\hline
\end{tabular}

${ }^{1}$ C07, Camelbeeck and others (2007); CO11, Clark and others (2011a); C97, Crone and others (1997); F05, Ferry and others (2005); L10, Leonard (2010); M01, Meghraoui and others (2001); WC94, Wells and Coppersmith (1994). 
Table 3. Selected prehistoric earthquakes in stable continental regions: Descriptions.

[Named feature is the landform that was studied. Scarps have been trenched to identify an underlying tectonic fault, which may have slipped in more than one earthquake. Each liquefaction field consists of mapped sand dikes that are all attributed to a single earthquake. Skelton and Vincennes liquefaction fields each straddle the Illinois-Indiana boundary. Age refers to the earthquake inferred to have formed the scarp or liquefaction field. If a scarp formed in two or more earthquakes, age refers to the youngest. If the cited reference gives age as a range, the midpoint is listed. Ka, thousands of years before present. Each Ref field cites sources of preceding one or two entries in that row. Latitude and longitude refer to scarp midpoint, trench location, or most intensely liquefied part of a liquefaction field]

\begin{tabular}{|c|c|c|c|c|c|c|}
\hline Feature name & Locale & Age (ka) & Ref $^{1}$ & Latitude & Longitude & $\operatorname{Ref}^{1}$ \\
\hline \multicolumn{7}{|c|}{ North America } \\
\hline Cheraw scarp & Colorado & 8 & C97 & $38.250^{\circ} \mathrm{N}$ & $103.429^{\circ} \mathrm{W}$ & C97 \\
\hline Elnora liquefaction field & Indiana & 2.0 & O98, M97 & $38.883^{\circ} \mathrm{N}$ & $87.119^{\circ} \mathrm{W}$ & M97 \\
\hline Idalia Hill scarp & Missouri & 12.8 & B06 & $36.837^{\circ} \mathrm{N}$ & $89.921^{\circ} \mathrm{W}$ & B04 \\
\hline Iona liquefaction field & Indiana & 4.0 & O98, M97 & $38.528^{\circ} \mathrm{N}$ & $87.419^{\circ} \mathrm{W}$ & M97 \\
\hline Martinsville liquefaction field & Indiana & 6.0 & O98, M97 & $39.508^{\circ} \mathrm{N}$ & $86.300^{\circ} \mathrm{W}$ & M97, O98 \\
\hline Meers scarp & Oklahoma & 1.2 & CL90 & $34.781^{\circ} \mathrm{N}$ & $98.467^{\circ} \mathrm{W}$ & CW00 \\
\hline Shoal Creek liquefaction field & Illinois & 6.5 & T99 & $38.638^{\circ} \mathrm{N}$ & $89.586^{\circ} \mathrm{W}$ & O98 \\
\hline Skelton liquefaction field & Indiana & 12 & O98, M97 & $38.371^{\circ} \mathrm{N}$ & $87.742^{\circ} \mathrm{W}$ & M97, O98 \\
\hline SE Reelfoot rift margin scarp & Tennessee & 2.2 & $\mathrm{C} 06$ & $35.643^{\circ} \mathrm{N}$ & $89.786^{\circ} \mathrm{W}$ & $\mathrm{C} 06$ \\
\hline Springfield liquefaction field & Illinois & 6.6 & MO99 & $40.074^{\circ} \mathrm{N}$ & $89.392^{\circ} \mathrm{W}$ & MO99, O98 \\
\hline Vallonia liquefaction field & Indiana & 3.95 & O98, M97 & $38.841^{\circ} \mathrm{N}$ & $86.100^{\circ} \mathrm{W}$ & M97,O98 \\
\hline Vincennes liquefaction field & Illinois & 6.1 & O98, M97 & $38.717^{\circ} \mathrm{N}$ & $87.750^{\circ} \mathrm{W}$ & M97, O98 \\
\hline \multicolumn{7}{|c|}{ Europe } \\
\hline Basel-Reinach scarp & Switzerland & 0.5 & F05 & $47.484^{\circ} \mathrm{N}$ & $7.591^{\circ} \mathrm{E}$ & F05 \\
\hline Bree scarp & Belgium & 5.5 & $\mathrm{C} 07$ & $51.077^{\circ} \mathrm{N}$ & $5.615^{\circ} \mathrm{E}$ & M00 \\
\hline Vilarica scarp & Portugal & 12.8 & R09 & $41.210^{\circ} \mathrm{N}$ & $7.189^{\circ} \mathrm{W}$ & R09 \\
\hline \multicolumn{7}{|c|}{ Australia } \\
\hline Burra scarp & South Australia & 83 & Q06 & $33.758^{\circ} \mathrm{S}$ & $139.094^{\circ} \mathrm{E}$ & $\mathrm{C} 11$ \\
\hline Cadell scarp & New South Wales & 20 & M12 & $35.963^{\circ} \mathrm{S}$ & $144.893^{\circ} \mathrm{E}$ & $\mathrm{C} 12$ \\
\hline Dumbleyung scarp & Western Australia & 8.6 & ER08 & $33.184^{\circ} \mathrm{S}$ & $117.692^{\circ} \mathrm{E}$ & $\mathrm{C} 11$ \\
\hline Lake Edgar scarp & Tasmania & 18 & $\mathrm{CO} 11$ & $43.029^{\circ} \mathrm{S}$ & $146.345^{\circ} \mathrm{E}$ & $\mathrm{C} 12$ \\
\hline Lort River scarp & Western Australia & 9.7 & ER08 & $33.480^{\circ} \mathrm{S}$ & $121.224^{\circ} \mathrm{E}$ & $\mathrm{C} 12$ \\
\hline Milendella scarp & South Australia & 14.8 & $\mathrm{C} 11$ & $34.609^{\circ} \mathrm{S}$ & $139.238^{\circ} \mathrm{E}$ & $\mathrm{C} 11$ \\
\hline Mundi Mundi scarp & New South Wales & 59.3 & Q06 & $31.823^{\circ} \mathrm{S}$ & $141.210^{\circ} \mathrm{E}$ & $\mathrm{C} 12$ \\
\hline North Hyden scarp & Western Australia & 20 & $\mathrm{C} 08$ & $32.279^{\circ} \mathrm{S}$ & $119.268^{\circ} \mathrm{E}$ & $\mathrm{C} 12$ \\
\hline Roopena scarp & South Australia & 28.5 & $\mathrm{C} 03$ & $32.866^{\circ} \mathrm{S}$ & $137.382^{\circ} \mathrm{E}$ & $\mathrm{C} 12$ \\
\hline Waratah scarp & New South Wales & 38 & G09 & $38.770^{\circ} \mathrm{S}$ & $146.056^{\circ} \mathrm{E}$ & $\mathrm{C} 11$ \\
\hline Wilkatana-Depot Creek scarp & South Australia & 30 & Q06 & $32.116^{\circ} \mathrm{S}$ & $137.956^{\circ} \mathrm{E}$ & $\mathrm{C} 11$ \\
\hline
\end{tabular}

${ }^{1}$ B04, Baldwin and others (2004); B06, Baldwin and others (2006); C03, Crone and others (2003); C06, Cox and others (2006); C07, Camelbeeck and others (2007); C08, Clark and others (2008); C11, Clark and others (2011b); C12, D. Clark (written commun., August 15, 2012, which updates the appendix of C11); CO11, Clark and others (2011a); C97, Crone and others (1997); CL90, Crone and Luza (1990); CW00, Crone and Wheeler (2000); ER08, Estrada-Roldan (2008); F05, Ferry and others (2005); G09, Gardner and others (2009); M00, Meghraoui and others (2000); M12, McPherson and others (2012); M97, Munson and others (1997); MO99, McNulty and Obermeier (1999); O98, Obermeier (1998); Q06, Quigley and others (2006); R09, Rockwell and others (2009); T99, Tuttle and others (1999). 
Table 4. Selected prehistoric earthquakes in stable continental regions: Analyses.

[Named feature is the landform that was studied. Scarps have been trenched to identify an underlying tectonic fault, which may have slipped in more than one earthquake. Each liquefaction field consists of mapped sand dikes that are all attributed to a single earthquake. L, scarp length; leaders (--), not a fault scarp; M, moment magnitude of the earthquake required to produce the named feature; $\sigma(\mathrm{M})$, standard deviation of M; Type, tectonic setting of the feature according to Johnston and others (1994); Mmax zone, the North American source zone of Petersen and others (2008) that is a tectonic analog to the setting of the named feature; Distance, kilometers between feature's location (table 3) and nearest SCR (stable continental region) boundary. "Text" refers the reader to a discussion in the text. Each Ref field cites sources of preceding one or two entries in that row; km, kilometers]

\begin{tabular}{|c|c|c|c|c|c|c|c|c|c|}
\hline Feature name & $\mathrm{L}(\mathrm{km})$ & Ref $^{1}$ & M & Ref 1 & $\sigma(\mathrm{M})$ & Ref $^{1}$ & Type $^{2}$ & Mmax zone ${ }^{3}$ & Distance $(\mathrm{km})$ \\
\hline \multicolumn{10}{|c|}{ North America } \\
\hline Cheraw scarp & 45 & CW00 & $7.1^{4}$ & Text & $0.13^{4}$ & Text & SCR & $\mathrm{C}$ & 131 \\
\hline Elnora liquefaction field & -- & -- & 6.0 & M97 & $0.60^{5}$ & Text & SCR & $\mathrm{C}$ & 1,094 \\
\hline Idalia Hill scarp & 17 & B04 & 6.4 & L10 & 0.14 & L10 & SCR & $\mathrm{C}$ & 900 \\
\hline Iona liquefaction field & -- & -- & 6.0 & O98 & $0.60^{5}$ & Text & SCR & $\mathrm{C}$ & 1,053 \\
\hline Martinsville liquefaction field & -- & -- & 6.2 & $\mathrm{O} 05$ & $0.50^{5}$ & Text & SCR & $\mathrm{C}$ & 1,145 \\
\hline Meers scarp & 37 & CW00 & 6.9 & L10 & 0.14 & L10 & SCR & EM & 440 \\
\hline Shoal Creek liquefaction field & -- & -- & 6.5 & MO99 & $0.50^{5}$ & Text & $\mathrm{SCR}$ & $\mathrm{C}$ & 1,073 \\
\hline Skelton liquefaction field & -- & -- & 6.7 & $\mathrm{O} 05$ & $0.40^{5}$ & Text & SCR & EM & 1,036 \\
\hline Southeast Reelfoot rift-margin scarp & 80 & $\mathrm{C} 06$ & 7.5 & L10 & 0.14 & L10 & SCR & EM & 753 \\
\hline Springfield liquefaction field & -- & -- & 6.5 & MO99 & $0.50^{5}$ & Text & SCR & $\mathrm{C}$ & 1,230 \\
\hline Vallonia liquefaction field & -- & -- & 6.3 & O05 & $0.50^{5}$ & Text & $\mathrm{SCR}$ & $\mathrm{C}$ & 1,085 \\
\hline Vincennes liquefaction field & -- & -- & 7.5 & Text & 0.30 & Text & SCR & Text & 1,067 \\
\hline \multicolumn{10}{|c|}{ Europe } \\
\hline Basel-Reinach scarp & 8 & M01 & $6.0^{4}$ & Text & $0.13^{4}$ & Text & TI & EM & 4.9 \\
\hline Bree scarp & 11.5 & $\mathrm{C} 07$ & $6.2^{4}$ & Text & $0.13^{4}$ & Text & SCR & EM & 484 \\
\hline Vilarica scarp & 75 & R09 & 7.4 & L10 & 0.14 & $\mathrm{~L} 10$ & SCR & $\mathrm{C}$ & 287 \\
\hline \multicolumn{10}{|c|}{ Australia } \\
\hline Burra scarp & 57.2 & $\mathrm{C} 12$ & 7.2 & L10 & 0.14 & L10 & SCR & $\mathrm{C}$ & 417 \\
\hline Cadell scarp & 80 & M12 & 7.5 & L10 & 0.14 & L10 & SCR & $\mathrm{C}$ & 535 \\
\hline Dumbleyung scarp & 35.7 & $\mathrm{C} 12$ & 6.9 & L10 & 0.14 & L10 & SCR & $\mathrm{C}$ & 357 \\
\hline Lake Edgar scarp & 26.6 & $\mathrm{C} 12$ & $6.7^{4}$ & Text & $0.13^{4}$ & Text & $\mathrm{SCR}$ & EM & 185 \\
\hline Lort River scarp & 40 & ER08 & 7.0 & L10 & 0.14 & L10 & SCR & $\mathrm{C}$ & 253 \\
\hline Milendella scarp & 54 & $\mathrm{C} 11$ & 7.2 & L10 & 0.14 & L10 & SCR & $\mathrm{C}$ & 348 \\
\hline Mundi Mundi scarp & 98 & Text & 7.6 & L10 & 0.14 & L10 & SCR & $\mathrm{C}$ & 702 \\
\hline North Hyden scarp & 32 & $\mathrm{C} 11$ & 6.8 & L10 & 0.14 & L10 & SCR & $\mathrm{C}$ & 420 \\
\hline Roopena scarp & 29.5 & $\mathrm{C} 11$ & 6.8 & L10 & 0.14 & L10 & SCR & $\mathrm{C}$ & 428 \\
\hline Waratah scarp & 37.2 & $\mathrm{C} 11$ & 6.9 & L10 & 0.14 & L10 & SCR & EM & 357 \\
\hline Wilkatana-Depot Creek scarp & 59 & $\mathrm{C} 11$ & 7.3 & L10 & 0.14 & L10 & SCR & $\mathrm{C}$ & 524 \\
\hline
\end{tabular}

${ }^{1}$ B04, Baldwin and others (2004); C06, Cox and others (2006); C07, Camelbeeck and others (2007); C11, Clark and others (2011b); C12, D. Clark (written commun., August 15, 2012, which updates the appendix of C11); CW00, Crone and Wheeler (2000); ER08, Estrada-Roldan (2008); L10, Leonard (2010); M01, Meghraoui and others (2001); M12, McPherson and others (2012); M97, Munson and others (1997); MO99, McNulty and Obermeier (1999); O05, Olson and others (2005); O98, Obermeier (1998); R09, Rockwell and others (2009).

${ }^{2} \mathrm{SCR}$, within a stable continental region and more than $40 \mathrm{~km}$ from its nearest boundary; TI, within a stable continental region but $40 \mathrm{~km}$ or less from the nearest boundary.

${ }^{3} \mathrm{C}$, craton of Petersen and others (2008); EM, extended margin of Petersen and others (2008). Also, see text.

${ }^{4}$ From table 2.

${ }^{5}$ From table 5. 
Table 5. Estimated standard deviations of magnitudes of prehistoric liquefying earthquakes, Illinois and Indiana.

[Listed in increasing order of area of liquefaction field. Each liquefaction field consists of mapped sand dikes that are all attributed to a single earthquake. Each Ref field cites source of preceding entry in that row. Sites are those at which the cited reference reports liquefaction features, most of which are sand dikes. $\mathrm{M}, \sigma(\mathrm{M})$, moment magnitude and its standard deviation, respectively. Km, kilometers]

\begin{tabular}{|c|c|c|c|c|c|c|c|}
\hline Liquefaction field & State & Area $\left(\mathrm{km}^{2}\right)$ & $\operatorname{Ref}^{1}$ & No. of sites ${ }^{2}$ & $\operatorname{Ref}^{1}$ & $M$ & $\sigma(\mathrm{M})$ \\
\hline Elnora & Indiana & $0^{3}$ & O98 & 1 & MM96 & 6.0 & 0.60 \\
\hline Iona & Indiana & $0^{3}$ & O98 & 1 & MM96 & 6.0 & 0.60 \\
\hline Vallonia & Indiana & $1,993^{4}$ & O98 & 16 & MM96 & 6.3 & 0.50 \\
\hline Martinsville & Indiana & $2,324^{4}$ & O98 & 5 & MM96 & 6.2 & 0.50 \\
\hline Shoal Creek & Illinois & $2,916^{4}$ & MO99 & 21 & MO99 & 6.5 & 0.50 \\
\hline Springfield & Illinois & $3,383^{4}$ & MO99 & 14 & MO99 & 6.5 & 0.50 \\
\hline Skelton & Half in Illinois, half in Indiana & $13,760^{4}$ & O98 & $8(16)$ & MM96 & 6.7 & 0.40 \\
\hline Vincennes & Two-thirds in Illinois, one-third in Indiana & $51,378^{4}$ & O98 & $49(147)$ & MM96 & 7.5 & $0.30^{5}$ \\
\hline
\end{tabular}

${ }^{1}$ MM96, Munson and Munson (1996); O98, Obermeier (1998); MO99, McNulty and Obermeier (1999).

${ }^{2}$ Munson and Munson (1996) tallied numbers of sites having recognized sand dikes throughout Indiana, including eight attributed to the Skelton earthquake and 49 assigned to the Vincennes earthquake. I do not know of any similar tally for Illinois. To estimate numbers of sites liquefied in both States by the earthquakes, I considered the fraction of each liquefaction field that is in Indiana. Then I doubled the Indiana tally for the Skelton earthquake and tripled the tally for the Vincennes earthquake to obtain the figures in parentheses.

${ }^{3}$ Earthquake is known only from sand dikes in a single exposure. M6.0 was chosen as slightly larger than the estimated threshold for liquefaction of the sediments in the exposure.

${ }^{4}$ Areas estimated from maps of liquefaction fields in Obermeier (1998) and McNulty and Obermeier (1999).

${ }^{5}$ See text. 
Table 6. Excluded features.

[Ref field cites source or sources that describe feature. L, scarp length; D, single-earthquake displacement, M, moment magnitude; SCR, stable continental region]

\begin{tabular}{|c|c|c|c|}
\hline Feature & Locale & Ref $^{1}$ & Reason for exclusion \\
\hline \multicolumn{4}{|c|}{ North America } \\
\hline Liquefaction features & Charlevoix, Quebec & TA10 & Unknown upper bound on $\mathrm{M}$. \\
\hline -------------do----------- & Toronto, Ontario & TD10 & ----------------do------------------ \\
\hline ------------do----------- & Marianna, Arkansas & TM10, TO06 & ---------------do---------'------- \\
\hline -------------do----------- & St. Louis, Missouri & $\mathrm{T} 12$ & ---------------do----------------- \\
\hline --------------do------------ & Arkansas and Louisiana & CG08, CO04, T12 & ----------------do-----. \\
\hline -------------do----------- & Newbury, Massachusetts & TS91 & ---------------do------------------' \\
\hline -------------'do------------ & Central Virginia & OM98 & ----------------do------------------ \\
\hline Hovey Lake fault & Kentucky & $\mathrm{CO} 08, \mathrm{CO} 09, \mathrm{~W} 05$ & L, D highly uncertain. \\
\hline \multicolumn{4}{|c|}{ Europe } \\
\hline Geleen fault & Belgium & C07, VA08, VB09 & L highly uncertain. \\
\hline Geleen fault & The Netherlands & $\mathrm{C} 07, \mathrm{H} 03, \mathrm{H} 05, \mathrm{VA} 08$ & Tectonic origin disputed. \\
\hline Peelrand fault & The Netherlands & VB02 & L, D highly uncertain. \\
\hline Rurrand fault & Germany & C07, L01, VV01 & Faulting history unclear. \\
\hline Markgrafneusiedl fault & Austria & D05, DH10, DH11, H11, HI05 & In orogen too young to be SCR. \\
\hline El Camp fault & Spain & B92, M01a, M01b & $\begin{array}{l}\text { In crust extended too recently to be } \\
\text { SCR. }\end{array}$ \\
\hline Mino River terraces & Portugal and Spain & V12 & Tectonic origin not shown. \\
\hline Tagus River Valley & Portugal & BO12, CB04, CV06 & No active fault trenched. \\
\hline \multicolumn{4}{|c|}{ Asia } \\
\hline Eupcheon fault & South Korea & K11 & $\begin{array}{l}\text { In crust extended too recently to be } \\
\text { SCR. }\end{array}$ \\
\hline
\end{tabular}

${ }^{1}$ B92, Bartrina and others (1992); BO12, Besana-Ostman and others (2012); C07, Camelbeeck and others (2007); CB04, Cabral and others (2004); CG08, Cox and Gordon (2008); CO04, Cox and others (2004); CO08, Counts and others (2008); CO09, Counts and others (2009); CV06, Carvalho and others (2006); D05, Decker and others (2005); DH10, Decker and Hintersberger (2010); DH11, Decker and Hintersberger (2011); H03, Houtgast and others (2003); H05, Houtgast and others (2005); H11, Hintersberger and others (2011); HI05, Hinsch and others (2005); K11, Kim and others (2011); L01, Lehmann and others (2001); M01a, Masana and others (2001a); M01b, Masana and others (2001b); OM98, Obermeier and McNulty (1998); T12, Tuttle and Hartleb (2012); TA10, Tuttle and Atkinson (2010); TD10, Tuttle and others (2010b); TM10, Tuttle and others (2010a); TO06, Tuttle and others (2006); TS91, Tuttle and Seeber (1991); V12, Viveen and others (2012); VA08, Vanneste and others (2008); VB02, van den Berg and others (2002); VB09, Vanderberghe and others (2009); VV01, Vanneste and Verbeeck (2001); W05, Woolery (2005). 


\section{References Cited}

Ambraseys, N.N., 1988, Engineering seismology: Earthquake Engineering and Structural Dynamics, v. 19, p. 1-105.

Baldwin, J.N., Witter, R., Vaughn, J.D., Harris, J., Sexton, J., Lake, M., and Forman, S., 2004, Paleoseismic investigation of the Idalia Hill fault zone along the Commerce geophysical lineament, Idalia, Missouri: Final Technical Report to U.S. Geological Survey for Award 03-HQ-GR-0095, 42 p., 1 pl.

Baldwin, J.N., Witter, R.C., Vaughn, J.D., Harris, J.B., Sexton, J.L., Lake, M., Forman, S.L., and Barron, A.D., 2006, Geological characterization of the Idalia Hill fault zone and its structural association with the Commerce geophysical lineament, Idalia, Missouri: Bulletin of the Seismological Society of America, v. 96, no. 6, p. 2281-2303.

Bartrina, M.T., Cabrera, L., Jurado, M.J., Guimera, J., and Roca, E., 1992, Evolution of the central Catalan margin of the Valencia trough (western Mediterranean): Tectonophysics, v. 203, p. 219-247.

Bear, G.W., Rupp, J.A., and Rudman, A.J., 1997, Seismic interpretation of the deep structure of the Wabash Valley fault system: Seismological Research Letters, v. 68, no. 4, p. 624-640.

Besana-Ostman, G.M., Vilanova, S.P., Nemser, E.S., Falcao-Flor, A., Heleno, S., Ferreira, H., and Fonseca, J.D., 2012, Large Holocene earthquakes in the Lower Tagus Valley fault zone, central Portugal: Seismological Research Letters, v. 83, no. 1, p. 67-76.

Bevington, P.R., and Robinson, D.K., 1992, Data reduction and error analysis for the physical sciences (2 ed.): New York, McGraw-Hill, 328 p.

Broadbent, T., and Allan Cartography, 1994, Appendix G-Maps of the stable continental regions, in Johnston, A.C., Coppersmith, K.J., Kanter, L.R., and Cornell, C.A., eds., The earthquakes of stable continental regions, v. 5: Palo Alto, Calif., Electric Power Research Institute, 15 plates, scales $1: 12,500,000$ and $1: 20,000,000$.

Cabral, J., Ribeiro, P., Figueiredo, P., Pimental, N., and Martins, A., 2004, The Azambuja fault-An active structure located in an intraplate basin with significant seismicity (Lower Tagus Valley, Portugal): Journal of Seismology, v. 8, p. 347-362.

Camelbeeck, T., Vanneste, K., Alexandre, P., Verbeeck, K., Petermans, T., Rosset, P., Everaerts, M., Warnant, R., and Van Camp, M., 2007, Relevance of active faulting and seismicity studies to assessments of long-term earthquake activity and maximum magnitude in intraplate northwest Europe, between the lower Rhine embayment and the North Sea, in Stein, S., and Mazzotti, S., eds., Continental intraplate earthquakes-Science, hazard, and policy issues: Boulder, Colo., Geological Society of America Special Paper 425, p. 193-224.

Carvalho, J., Cabral, J., Goncalves, R., Torres, L., and Mendes-Victor, L., 2006, Geophysical methods applied to fault characterization and earthquake potential assessment in the Lower Tagus Valley, Portugal: Tectonophysics, v. 418, p. 277-297.

Castilla, R.A., and Audemard, F.A., 2007, Sand blows as a potential tool for magnitude estimation of pre-instrumental earthquakes: Journal of Seismology, v. 11, p. 473-487.

Chinnery, M.A., 1979, Investigations of the seismological input to the safety design of nuclear power reactors in New England: U.S. Nuclear Regulatory Commission report NUREG/CR-0563, 72 p.

Clark, D., Cupper, M., Sandiford, M., and Kiernan, K., 2011a, Style and timing of late Quaternary faulting on the Lake Edgar fault, southwest Tasmania, Australia-Implications for hazard assessment in intracratonic areas, in Audemard, F.A., Michetti, A.M., and McCalpin, J.A., eds., Geological criteria for evaluating seismicity revisited-Forty years of paleoseismic investigations and the natural record of past earthquakes: Boulder, Colo., Geological Society of America Special Paper 479, p. 109-131. 
Clark, D., McPherson, A., and Collins, C., 2011b, Australia's seismogenic neotectonic record-A case for heterogeneous intraplate deformation: Geoscience Australia Record 2011/11, 95 p.

Clark, D., Dentith, M., Wyrwoll, K.-H., Yanchou, L., Dent, V., and Featherstone, C., 2008, The Hyden fault scarp, Western Australia-Paleoseismic evidence for repeated Quaternary displacement in an intracratonic setting: Australian Journal of Earth Sciences, v. 55, p. 379-395.

Coppersmith, K.J., 1994, Conclusions regarding maximum earthquake assessment, in Johnston, A.C., Coppersmith, K.J., Kanter, L.R., and Cornell, C.A., eds., The earthquakes of stable continental regions, v. 1: Palo Alto, Calif., Electric Power Research Institute, p. 6-1-6-24.

Coppersmith, K.J., Johnston, A.C., Metzger, A.G., and Arabasz, W.J., 1987, Methods for assessing maximum earthquakes in the Central and Eastern United States: Palo Alto, Calif., Electric Power Research Institute, working report EPRI RP2556-12, 312 p.

Counts, R.C., Van Arsdale, R.B., and Woolery, E.W., 2009, Investigation of Quaternary displacement on the Uniontown fault, western Kentucky [abs.]: Geological Society of America Abstracts with Programs, v. 41, no. 1, p. 20.

Counts, R.C., Woolery, E., and Van Arsdale, R.B., 2008, Quaternary faulting in Union County, Kentucky_Preliminary results [abs.]: Geological Society of America Abstracts with Programs, v. 40, no. 5 , p. 80 .

Cox, R.T., Cherryhomes, J., Harris, J.B., Larsen, D., Van Arsdale, R.B., and Forman, S.L., 2006, Paleoseismology of the southeastern Reelfoot rift in western Tennessee and implications for intraplate fault zone evolution: Tectonics, v. 25, 17 p.

Cox, R.T., and Gordon, J., 2008, Sand blows on late Quaternary surfaces in northeast Louisiana [abs.]: Geological Society of America Abstracts with Programs, v. 40, no. 6, p. 151.

Cox, R.T., Larsen, D., Forman, S.L., Woods, J., Morat, J., and Galluzzi, J., 2004, Preliminary assessment of sand blows in the southern Mississippi embayment: Bulletin of the Seismological Society of America, v. 94, no. 3, p. 1,125-1,142.

Cox, R.T., Van Arsdale, R.B., Harris, J.B., and Larsen, D., 2001, Neotectonics of the southeastern Reelfoot rift margin, Central United States, and implications for regional strain accommodation: Geology, v. 29, no. 5, p. 419-422.

Crone, A.J., De Martini, P.M., Machette, M.N., Okumura, K., and Prescott, J.R., 2003, Paleoseismicity of two historically quiescent faults in Australia-Implications for fault behavior in stable continental regions: Bulletin of the Seismological Society of America, v. 93, p. 1913-1934.

Crone, A.J., and Luza, K.V., 1990, Style and timing of Holocene surface faulting on the Meers fault, southwestern Oklahoma: Geological Society of America Bulletin, v. 102, p. 1-17.

Crone, A.J., Machette, M.N., Bradley, L.A., and Mahan, S.A., 1997, Late Quaternary surface faulting on the Cheraw fault, southeastern Colorado: U.S. Geological Survey Miscellaneous Investigations Map I-2591, 1 sheet, pamphlet, 7 p., accessed on February 12, 2014, at http://pubs.usgs.gov/imap/i2591/I2591.pdf.

Crone, A.J., and Wheeler, R.L., 2000, Data for Quaternary faults, liquefaction features, and possible tectonic features in the Central and Eastern United States, east of the Rocky Mountain front: U.S. Geological Survey Open-File Report 2000-0260, 341 p.

Decker, K., and Hintersberger, E., 2010, Characterizing very slow faults in an active pull-apart setting, Vienna basin, Austria [abs.]: Seismological Research Letters, v. 81, no. 2, p. 325.

Decker, K., and Hintersberger, E., 2011, Assessing maximum credible earthquake (MCE) magnitudes for a slow intra-plate fault system in the Vienna basin, Austria [abs.]: Seismological Research Letters, v. 82 , no. 2 , p. 301 . 
Decker, K., Peresson, H., and Hinsch, R., 2005, Active tectonics and Quaternary basin formation along the Vienna basin transform fault: Quaternary Science Reviews, v. 24, p. 307-322.

Electric Power Research Institute (EPRI), United States Department of Energy, and United States Nuclear Regulatory Commission, 2012, Technical report-Central and Eastern United States seismic source characterization for nuclear facilities: Palo Alto, Calif., Electric Power Research Institute, United States Department of Energy, and United States Nuclear Regulatory Commission, 6 v., 2,685 p., accessed on February 12, 2014, at http://www.ceus-ssc.com/index.htm.

Estrada-Roldan, B.E., 2008, Neotectonic and paleoseismological studies in the southwest of Western Australia: Nedlands, Western Australia, Australia, University of Western Australia, Ph.D. dissertation, $362 \mathrm{p}$.

Ferry, M., Meghraoui, M., Delouris, B., and Giardini, D., 2005, Evidence for Holocene paleoseismicity along the Basel-Reinach active normal fault (Switzerland) - A seismic source for the 1356 earthquake in the upper Rhine graben: Geophysical Journal International, v. 160, p. 554-572.

Frankel, A., Mueller, C., Barnhard, T., Perkins, D., Leyendecker, E.V., Dickman, N., Hanson, S., and Hopper, M., 1996, National seismic-hazard maps-Documentation June 1996: U.S. Geological Survey Open-File Report 1996-532, 70 p., accessed on February 12, 2014, at http://pubs.er.usgs.gov/usgspubs/ofr/ofr96532.

Frankel, A.D., Petersen, M.D., Mueller, C.S., Haller, K.M., Wheeler, R.L., Leyendecker, E.V., Wesson, R.L., Harmsen, S.C., Cramer, C.H., Perkins, D.M., and Rukstales, K.S., 2002, Documentation for the 2002 update of the national seismic hazard maps: U.S. Geological Survey Open-File Report 20020420, 39 p., accessed on February 12, 2014, at http://pubs.er.usgs.gov/usgspubs/ofr/ofr02420.

Gardner, T., Webb, J., Pezzia, C., Amborn, T., Tunnell, R., Flanagan, S., Merritts, D., Marshall, J., Fabel, D., and Cupper, M.L., 2009, Episodic intraplate deformation of stable continental marginsEvidence from late Neogene and Quaternary marine terraces, Cape Liptrap, southeastern Australia: Quaternary Science Reviews, v. 28, p. 39-53.

Gradstein, F., Ogg, J., and Smith, A., eds., 2004, A geologic time scale 2004: Cambridge, United Kingdom, Cambridge University Press, 589 p., 1 folded plate.

Green, R.L., Obermeier, S.F., and Olson, S.M., 2005, Engineering geologic and geotechnical analysis of paleoseismic shaking using liquefaction effects_Field examples: Engineering Geology, v. 76, p. 263-293.

Harrison, R.W., Hoffman, D., Vaughn, J.D., Palmer, J.R., Wiscombe, C.L., McGeehin, J.P., Stephenson, W.J., Odum, J.K., Williams, R.A., and Forman, S.L., 1999, An example of neotectonism in a continental interior-Thebes Gap, Midcontinent, United States: Tectonophysics, v. 305, p. 399-417.

Hildenbrand, T.G., and Hendricks, J.D., 1995, Geophysical setting of the Reelfoot rift and relations between rift structures and the New Madrid seismic zone: U.S. Geological Survey Professional Paper $1538-\mathrm{E}, 30 \mathrm{p}$.

Hinsch, R., Decker, K., and Wagreich, M., 2005, 3-D mapping of segmented active faults in the southern Vienna basin: Quaternary Science Reviews, v. 24, p. 321-336.

Hintersberger, E.M., Decker, K., and Lomax, J., 2011, The extended (paleo)seismological story of the Vienna basin and the largest earthquake north of the Alps [abs.]: Seismological Research Letters, V. 82, no. 2, p. 301-302.

Houtgast, R.F., Van Balen, R.T., and Kasse, C., 2005, Late Quaternary evolution of the Feldbiss fault (Roer Valley rift system, The Netherlands) based on trenching, and its potential relation to glacial unloading: Quaternary Science Reviews, v. 24, p. 491-510. 
Houtgast, R.F., Van Balen, R.T., Kasse, C., and Vandenberghe, J., 2003, Late Quaternary tectonic evolution and postseismic near surface fault displacements along the Geleen fault (Feldbiss fault zone-Roer Valley rift system, The Netherlands), based on trenching: Netherlands Journal of Earth Sciences/Geologie en Mijnbouw, v. 82, no. 2, p. 177-196.

Johnston, A.C., 1989a, The effect of large ice sheets on earthquake genesis, in Gregersen, S., and Basham, P.W., eds., Earthquakes at North-Atlantic passive margins-Neotectonics and postglacial rebound: Dordrecht, The Netherlands, Kluwer Academic Publishers, p. 581-599.

Johnston, A.C., 1989b, The seismicity of "stable continental interiors," in Gregersen, S., and Basham, P.W., eds., Earthquakes at North-Atlantic passive margins - Neotectonics and postglacial rebound: Dordrecht, The Netherlands, Kluwer Academic Publishers, p. 299-327.

Johnston, A.C., 1994, Seismotectonic interpretations and conclusions from the stable continental region seismicity database, in Johnston, A.C., Coppersmith, K.J., Kanter, L.R., and Cornell, C.A., eds., The earthquakes of stable continental regions-v. 1: Palo Alto, Calif., Electric Power Research Institute, p. 4-1-4-103.

Johnston, A.C., 1996a, Seismic moment assessment of earthquakes in stable continental regions-I. Instrumental seismicity: Geophysical Journal International, v. 124, p. 381-414.

Johnston, A.C., 1996b, Seismic moment assessment of earthquakes in stable continental regions-II. Historical seismicity: Geophysical Journal International, v. 125, p. 639-678.

Johnston, A.C., 1996c, Seismic moment assessment of earthquakes in stable continental regions-III. New Madrid 1811-1812, Charleston 1886 and Lisbon 1755: Geophysical Journal International, v. 126, p. 314-344.

Johnston, A.C., Coppersmith, K.J., Kanter, L.R., and Cornell, C.A., eds., 1994, The earthquakes of stable continental regions: Palo Alto, Calif., Electric Power Research Institute, 5 v., 2,519 p., 16 folded plates, 1 diskette, accessed on February 12, 2014, at

http://www.epri.com/search/Pages/Default.aspx.

Kanter, L.R., 1994, Tectonic interpretation of stable continental crust, in Johnston, A.C., Coppersmith, K.J., Kanter, L.R., and Cornell, C.A., eds., The earthquakes of stable continental regions, v. 1: Palo Alto, Calif., Electric Power Research Institute, p. 2-1-2-98, accessed on February 12, 2014, at http://www.epri.com/search/Pages/Default.aspx.

Kim, Y.-S., Kihm, J.-H., and Jin, K., 2011, Interpretation of rupture history of a low slip-rate active fault by analysis of progressive displacement accumulation-An example from the Quaternary Eupcheon fault, SE Korea: Journal of the Geological Society, London, v. 168, p. 273-288.

Lehmann, K., Klostermann, J., and Pelzing, R., 2001, Paleoseismological investigations at the Rurrand fault, lower Rhine embayment: Netherlands Journal of Earth Sciences/Geologie en Mijnbouw, v. 80, no. 3-4, p. 139-154.

Leonard, M., 2010, Earthquake fault scaling-Self-consistent relating of rupture length, width, average displacement, and moment release: Bulletin of the Seismological Society of America, v. 100, no. 5A, p. 1971-1988.

Lundqvist, J., and Lagerback, R., 1976, The Paarve fault-A late-glacial fault in the Precambrian of Swedish Lapland: Geologiska Foreningens i Stockholm Forhandlingar, v. 98, p. 45-51.

Masana, E., Villamarin, J.A., Sanchez Cabanero, J., Plaza, J., and Santanach, P., 2001a, Seismogenic faulting in an area of low seismic activity_Paleoseismicity of the El Camp fault (Northeast Spain): Netherlands Journal of Earth Sciences/Geologie en Mijnbouw, v. 80, no. 3-4, p. 229-241.

Masana, E., Villamarin, J.A., and Santanach, P., 2001b, Paleoseismic results from multiple trenching analysis along a silent fault_-The El Camp fault (Tarragona, northeastern Iberian Peninsula): Acta Geologica Hispanica, v. 36, no. 3-4, p. 329-354. 
McCalpin, J.P., ed., 2009, Paleoseismology (2nd ed.): Amsterdam, The Netherlands, Academic Press, $649 \mathrm{p}$.

McNulty, W.E., and Obermeier, S.F., 1999, Liquefaction evidence for at least two strong Holocene paleo-earthquakes in central and southwestern Illinois, USA: Environmental and Engineering Geoscience, v. 5, p. 133-146.

McPherson, A., Clark, D., Cupper, M., Collins, C.D.N., and Nelson, G., 2012, The Cadell fault-A record of long-term fault behavior in south-eastern Australia, in Churchman, G., Cresswell, R., and Singh, B., eds., Combined Australian Regolith Scientists Association and Australian Clay Minerals Society, Proceedings, February 7-9, 2012: Mildura, Victoria, Australia, p. 7-16.

Meghraoui, M., Camelbeeck, T., Vanneste, K., Brondeel, M., and Jongmans, D., 2000, Active faulting and paleoseismology along the Bree fault, lower Rhine graben, Belgium: Journal of Geophysical Research, v. 105, no. B6, p. 13,809-13,841.

Meghraoui, M., Delouis, B., Ferry, M., Giardini, D., Huggenberger, P., Spottke, I., and Granet, M., 2001, Active normal faulting in the upper Rhine graben and paleoseismic identification of the 1356 Basel earthquake: Science, v. 293, p. 2070-2073.

Morner, N.-A., 2004, Active faults and paleoseismicity in Fennoscandia, especially Sweden-Primary structures and secondary effects: Tectonophysics, v. 380, p. 139-157.

Morner, N.-A., 2005, An interpretation and catalog of paleoseismicity in Sweden: Tectonophysics, v. 408, p. 265-307.

Muir Wood, R., 1989, Extraordinary deglaciation reverse faulting in northern Fennoscandia, in Gregersen, S., and Basham, P.W., eds., Earthquakes at North-Atlantic passive margins-Neotectonics and postglacial rebound: Dordrecht, The Netherlands, Kluwer Academic Publishers, p. 141-173.

Munson, P.J., and Munson, C.A., 1996, Paleoliquefaction evidence for recurrent strong earthquakes since 20,000 years BP in the Wabash Valley area of Indiana: Final Technical Report to U. S. Geological Survey for Award 14-08-0001-02117, 137 p.

Munson, P.J., Obermeier, S.F., Munson, C.A., and Hajic, E.R., 1997, Liquefaction evidence for Holocene and latest Pleistocene seismicity in the southern halves of Indiana and Illinois-A preliminary overview: Seismological Research Letters, v. 68, no. 4, p. 521-536.

Nelson, W.J., 1995, Structural features in Illinois: Illinois State Geological Survey Bulletin 100, 144 p., 2 folded maps, scales 1:500,000 and 1:250,000.

Obermeier, S.F., 1998, Liquefaction evidence for strong earthquakes of Holocene and latest Pleistocene ages in the States of Indiana and Illinois, USA: Engineering Geology, v. 50, p. 227-254.

Obermeier, S.F., 2009, Using liquefaction-induced and other soft-sediment features for paleoseismic analysis, in McCalpin, J.P., ed., Paleoseismology (2nd ed.): Burlington, Mass., Academic Press, p. 497-564.

Obermeier, S.F., and McNulty, W.E., 1998, Paleoliquefaction evidence for seismic quiescence in central Virginia during late and middle Holocene time [abs.]: EOS, Transactions of the American Geophysical Union, v. 79, no. 17 (Supplement), p. S342.

Olson, S.M., Green, R.L., and Obermeier, S.F., 2005, Revised magnitude-bound relation for the Wabash Valley region of the Central United States: Seismological Research Letters, v. 76, no. 6, p. 756-771.

Olson, S.M., Muhammad, K., Wen, Y., and Song, J., 2007, Uncertainties in paleoliquefaction analysis - Preliminary findings, in Geo-Denver 2007-New peaks in geotechnics, 2007: Denver, Colo., American Society of Civil Engineers, p. 1-10.

Parrish, Shane, and Van Arsdale, Roy, 2004, Faulting along the southeastern margin of the Reelfoot rift in northwestern Tennessee revealed in deep seismic-reflection profiles: Seismological Research Letters, v. 75, no. 6, p. 784-793. 
Petersen, M.D., Frankel, A.D., Harmsen, S.C., Mueller, C.S., Haller, K.M., Wheeler, R.L., Wesson, R.L., Zeng, Y., Boyd, O.S., Perkins, D.M., Luco, N., Field, E.H., Wills, C.J., and Rukstales, K.S., 2008, Documentation for the 2008 update of the United States national seismic hazard maps: U.S. Geological Survey Open-File Report 2008-1128, 119 p., accessed February 12, 2014, at http://pubs.usgs.gov/of/2008/1128/.

Quigley, M.C., Cupper, M.L., and Sandiford, M., 2006, Quaternary faults of south-central AustraliaPalaeoseismicity, slip rates and origin: Australian Journal of Earth Sciences, v. 53, p. 285-301.

Rajendran, C.P., and Rajendran, K., 2001, Characteristics of deformation and past seismicity associated with the 1819 Kutch earthquake, northwestern India: Bulletin of the Seismological Society of America, v. 91, no. 3, p. 407-426.

Rockwell, T., Fonseca, J., Madden, C., Dawson, T., Owen, L.A., Vilanova, S., and Figueiredo, P., 2009, Palaeoseismology of the Vilarica segment of the Manteigas-Braganca fault in northeastern Portugal, in Reicherter, K., Michetti, A.M., and Silva, P.G., eds., Palaeoseismology-Historical and prehistorical records of earthquake ground effects for seismic hazard assessment: London, England, The Geological Society of London Special Publication 316, p. 237-258.

Talwani, P., and Schaeffer, W.T., 2001, Recurrence rates of large earthquakes in the South Carolina Coastal Plain based on paleoliquefaction data: Journal of Geophysical Research, v. 106, no. B4, p. 6621-6642.

Tuttle, M., Al-Kadi, O., Mahdi, H., and Al-Shukri, H.J., 2010a, Repeated large earthquakes 4,800 to 38,000 years ago towards the southwestern end of the Reelfoot rift fault system [abs.]: Geological Society of America Abstracts with Programs, v. 42, no. 5, p. 218.

Tuttle, M.P., Dyer-Williams, K., Schroeder, H.A., and Herlihy, C.J., 2010b, Late Quaternary earthquake-induced liquefaction features in Greater Toronto [abs.]: Seismological Research Letters, v. 82 , no. 1, p. 150.

Tuttle, M., Chester, J., Lafferty, R., Dyer-Williams, K., and Cande, R., 1999, Paleoseismology study northwest of the New Madrid seismic zone: Nuclear Regulatory Commission Report NUREG/CR5730,155 p.

Tuttle, M.P., and Hartleb, R.D., 2012, Appendix E-CEUS paleoliquefaction database, uncertainties associated with paleoliquefaction data, and guidance for seismic source characterization, in Electric Power Research Institute, United States Department of Energy, and United States Nuclear Regulatory Commission, eds., Technical report - Central and Eastern United States seismic source characterization for nuclear facilities: Palo Alto, Calif., Electric Power Research Institute, United States Department of Energy, and United States Nuclear Regulatory Commission, p. E-1-E-135.

Tuttle, M.P., Al-Shukri, H., and Mahdi, H., 2006, Very large earthquakes centered southwest of the New Madrid seismic zone 5,000-7,000 years ago: Seismological Research Letters, v. 77, no. 6, p. 755-770.

Tuttle, M.P., and Atkinson, G.M., 2010, Localization of large earthquakes in the Charlevoix seismic zone, Quebec, Canada, during the past 10,000 years: Seismological Research Letters, v. 81, no. 1, p. 140-147.

Tuttle, M.P., Schweig, E.S., Sims, J.D., Lafferty, R.H., Wolf, L.W., and Haynes, M.L., 2002, The earthquake potential of the New Madrid seismic zone: Bulletin of the Seismological Society of America, v. 92, p. 2080-2089.

Tuttle, M.P., and Seeber, L., 1991, Historic and prehistoric earthquake-induced liquefaction in Newbury, Massachusetts: Geology, v. 19, p. 594-597.

van den Berg, M., Vanneste, K., Dost, B., Lokhorst, A., van Eijk, M., and Verbeeck, K., 2002, Paleoseismic investigations along the Peel boundary fault - Geological setting, site selection and 
trenching results: Netherlands Journal of Earth Sciences/Geologie en Mijnbouw, v. 81, no. 1, p. 39-60.

Vanderberghe, D., Vanneste, K., Verbeeck, K., Paulissen, E., Buylaert, J.-P., DeCorte, F., and Van den houte, P., 2009, Late Weichselian and Holocene earthquake events along the Geleen fault in NE Belgium-OSL constraints: Quaternary International, v. 199, p. 56-74.

Vanneste, K., Mees, F., and Verbeeck, K., 2008, Thin-section analysis as a tool to aid identification of paleoearthquakes on the "slow," active Geleen fault, Roer Valley graben: Tectonophysics, v. 453, p. 94-109.

Vanneste, K., and Verbeeck, K., 2001, Paleoseismological analysis of the Rurrand fault near Julich, Roer Valley graben, Germany-Coseismic or aseismic faulting history?: Netherlands Journal of Earth Sciences/Geologie en Mijnbouw, v. 80, no. 3-4, p. 155-169.

Vaughn, J.D., 1994, Paleoseismological studies in the western lowlands of southeast Missouri: Final Technical Report to U.S. Geological Survey for Award 14-08-0001-G1931, 29 p.

Viveen, W., van Balen, R.T., Schoorl, J.M., Veldkamp, A., Temme, A.J.A.M., and Vidal-Romani, J.R., 2012, Assessment of recent tectonic activity on the NW Iberian Atlantic margin by means of geomorphic indices and field studies of the lower Mino River terraces: Tectonophysics, v. 544-545, p. $13-30$.

Wells, D.L., and Coppersmith, K.J., 1994, New empirical relationships among magnitude, rupture length, rupture width, rupture area, and surface displacement: Bulletin of the Seismological Society of America, v. 84, p. 974-1002.

Wheeler, R.L., 2008, Paleoseismic targets, seismic hazard, and urban areas in the Central and Eastern United States: Bulletin of the Seismological Society of America, v. 98, no. 3, p. 1572-1580.

Wheeler, R.L., 2009a, Methods of Mmax estimation east of the Rocky Mountains: U.S. Geological Survey Open-File Report 2009-1018, 43 p., accessed on February 12, 2014, at http://pubs.usgs.gov/of/2009/1018/.

Wheeler, R.L., 2009b, Sizes of the largest possible earthquakes in the Central and Eastern United States-Summary of a workshop, September 8-9, 2008, Golden, Colo.: U.S. Geological Survey Open-File Report 2009-1263, 304 p., accessed February 12, 2014, at http://pubs.usgs.gov/of/2009/1263.

Wheeler, R.L., and Cramer, C.H., 2002, Updated seismic hazard in the southern Illinois BasinGeological and geophysical foundations for use in the 2002 USGS national seismic-hazard maps: Seismological Research Letters, v. 73, no. 5, p. 776-791.

Wheeler, R.L., and Frankel, A., 2000, Geology in the 1996 USGS seismic-hazard maps, Central and Eastern United States: Seismological Research Letters, v. 71, no. 2, p. 273-282.

Woolery, E.W., 2005, Geophysical and geological evidence of neotectonic deformation along the Hovey Lake fault, lower Wabash Valley fault system, Central United States: Bulletin of the Seismological Society of America, v. 95, no. 3, p. 1193-1201.

Wyatt, D.E., Jr., and Stearns, R.G., 1988, Possible active fault zones in west Tennessee interpreted from surface lineaments and magnetic and gravity anomalies: Southeastern Geology, v. 28, no. 4, p. 191-210. 